Karaduman, H. (2018). Soyuttan somuta, sanaldan gerçeğe: öğretmen adaylarının bakış açısıyla üç boyutlu yazıcılar. Abant İzzet Baysal Üniversitesi Eğitim Fakültesi Dergisi, 18 (1), 273-303.

\title{
SOYUTTAN SOMUTA, SANALDAN GERÇEĞE: ÖĞRETMEN ADAYLARININ BAKIŞ AÇISIYLA ÜÇ BOYUTLU YAZICILAR*
}

\author{
Hidir KARADUMAN**
}

\section{ÖZET}

$\mathrm{Bu}$ araştırmanın amacı sosyal bilgiler öğretmen adaylarının 3 boyutlu yazıcılar ve bu yazıcılar aracılığıyla alınan modellere ilişkin görüşlerini ve öğretmen adaylarının bakış açısıyla bu modellerin sosyal bilgiler dersine katkısını saptamaktır. Çalışmada nitel araştırma yaklaşımına dayalı olarak olgubilim deseni kullanılmışır. Araştırmanın çalışma grubunun belirlenmesinde amaçlı örnekleme yöntemlerinden ölçüt örneklemeden yararlanılmıştır. Bu kapsamda araştırma, 2015-2016 güz yarıyılında bir devlet üniversitesinin Sosyal Bilgiler Öğretmenliği Programında öğrenim gören ve "Sosyal Bilgiler Ders Kitabı İncelemeleri" dersinde 3 boyutlu yazıcıyla ilişkilendirilmiş ders planı hazırlayan 20 öğrenciyle yarı yapılandırılmış görüşmeler aracılığıyla gerçekleştirilmiştir. Verilerin analizinde tümevarımsal analiz yaklaşımı benimsenmiştir. Araştırma sonucunda öğretmen adayları, üç boyutlu yazıcıları soyutu somuta dönüştüren, öğrenme-öğretme sürecini destekleyecek materyalleri kullanışlı bir biçimde üretilebilen, üçüncü boyutu öğrenmeögretme sürecine katan, dokunma duyusunu harekete geçiren ve bu bağlamda kolaylık sağlayan devrimsel bir teknoloji olarak tanımlanmıştır. Öğretmen adaylarının 3 boyutlu yazıcılar ve bu yazıcılar aracılığıyla alınan modellerin sosyal bilgiler dersine katkılarına yönelik değerlendirmelerinde de "soyuttan somuta dönüşüm" etkisi ön plana çıkmıştır. Araştırmada elde edilen sonuçlar doğrultusunda öğretmen adaylarının, 3 boyutlu yazıcılar konusunda bilgi ve deneyim kazanmalarına yönelik öneriler sunulmuştur.

Anahtar Kelimeler: Sosyal bilgiler, sosyal bilgiler öğretmen adayı, 3 boyutlu yazıcı

\section{ABSTRACT TO CONCRETE \& VIRTUAL TO REAL: THREE- DIMENSIONAL PRINTERS FROM THE PERSPECTIVE OF TEACHER CANDIDATES}

\section{ABSTRACT}

The aim of this study was to identify the views of social studies teacher candidates on three dimensional printers as well as the models obtained through these printers, and the effects of these models on the social studies course. In the study, the phenomenological design was used in accordance with the qualitative research method. Criterion sampling, a purposeful sampling method, was employed in the selection of the participants. In this scope, the study was conducted through semi-structured interviews with 20 students who were studying social studies education in the 2015-2016 academic year and prepared lesson plans related to three-dimensional printers in the "Examinations of Social Studies Course Book" course. An inductive approach was adopted in the analysis of data. As a result, the teacher candidates defined three-dimensional printers as a technology that turns abstract to concrete, can produce materials to support the instructional process in a useful way, adds the third dimension to this process, triggers the sense of touch, and in this regard, makes learning easier. As for the effect of three-dimensional printers and the models obtained through these printers on the social studies course, the teacher candidates emphasised "the transformation from abstract to concrete" in their evaluation. Suggestions towards teacher candidates were presented based on the results of the study.

Key Words: Social studies, social studies teacher candidates, three-dimensional printers

\footnotetext{
* Bu araştırma Anadolu Üniversitesi Bilimsel Araştırma Projeleri Komisyonu Başkanlığı tarafindan desteklenmiștir. Proje No: 1605E504

** Anadolu Üniversitesi Ë̆itim Fakültesi Sosyal Bilimler ve Türkçe Eğitimi Bölümü / Sosyal Bilgiler Eğitimi AnabilimDal, hidirk@anadolu.edu.tr
} 


\section{GİRIŞ}

Son yıllarda 3 boyutlu yazdırma, dijital tasarımlardan fiziksel nesneler oluşturmak için kullanılan bir yöntem olarak (Hoy, 2013) özellikle tıp, mühendislik, sanat, eğitim gibi pek çok alanda kullanılmaya başlanmıştır. The Economist 2011 yılındaki sayısında 3 boyutlu yazdırma teknolojisinden "dünyayı değiştirecek üretim teknolojisi” olarak bahsetmekte (Ratto ve Ree, 2012) ve bu teknolojinin yakın gelecekte buhar motoru, atom enerjisi, mikroçipler ve internet gibi, devrimsel bir değişime yol açacağı öngörülmektedir (Campbell, Williams, Ivanova ve Garrett, 2011). 3 Boyutlu yazdırma, dünyadaki tüketim, üretim ve yaşam biçimini değiştirmeyi gerçekleştirebilecek bir teknoloji olarak görülmektedir (Prince, 2014).

Üç boyutlu yazdırma işlemi sanal olarak tasarlanmış olan dijital objelerin farklı türden materyaller üzerine katı hale dönüştürülebilmesi işlemidir (Balcıŏglu, 2014). Bu işlem sayesinde dijital objelerin gerçekliğe dönüşümü sağlanmış olmaktadır. Bu işlemi gerçekleştiren makineler, kâğıt üzerine yazı aktaran ve azami iki boyuta kadar ulaşabilen klasik makinelerden farklı olarak cisimleri fiziksel gerçeklikleri ile hayata aktarabilmesinden dolayı üç boyutlu yazıcılar olarak adlandırılmaktadır (Hoy, 2013). Üç boyutlu yazıcıların üretim sürecine Şekil 1'de yer verilmektedir.

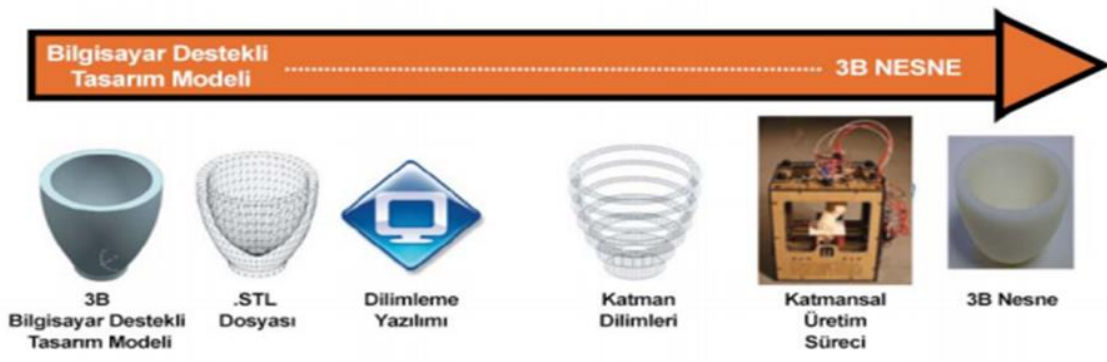

\section{Şekil 1. Üç boyutlu yazıcıların üretim süreci}

Katmansal Üretim Süreci (Campbell, Williams, Ivanova ve Garrett, 2011, s.3; Akt: Demir Kuzu ve diğerleri, 2016)

Şekil 1'de görüldüğü gibi üç boyutlu yazıcıların üretimi gerçekleştirebilmesi için öncelikle üç boyutlu bilgisayar destekli bir tasarım modeline ihtiyaç duyulmaktadır. Bu modeller üç farklı şekilde elde edilebilmektedir. Birinci yöntemde internet üzerindeki çeşitli sitelerde yer alan (örneğin: www.thingiverse.com; www.myminifactory.com) hazır modellerin indirilmesi sağlanarak yazdırılacak modeller elde edilebilmektedir. İkinci yöntem ise, üç boyutlu modelleme yazılımları (örneğin: SolidWorks, AutoCad) veya bunu sağlayan internet siteleri (örneğin: Thinkercad; 123D Design; Google SketchUp vb.) aracılığıyla kullanıcının kendi üç boyutlu modelini bilgisayar ortamında oluşturmasıdır. Bir diğer yöntem ise 3 boyutlu tarayıcılar aracılığıyla her hangibir kişi veya nesnenin taranarak yazdırılmaya hazır modelinin oluşturulmasıdır. Modeller oluşturulduktan sonra dosya uzantısı, bir 3 boyutlu bilgisayar destekli tasarım formatı olan .STL olarak dijital ortamlarda tutulmaktadır. Bu aşamadan sonra dilimleme yazılımları aracılığıyla dilimleme işlemi gerçekleştirilmekte ve nesne katmanlarına ayrılmaktadır. $\mathrm{Bu}$ işlem gerçekleştirildikten sonra bilgisayar ile doğrudan bağlantı kurularak veya Sd kart aracılığıyla yazdırma işlemi başlatılabilmektedir (Demir Kuzu ve 
Soyuttan somuta, sanaldan gerçeğe: öğretmen adaylarının bakış açısıyla üç boyutlu ...

diğerleri, 2016). 3 boyutlu yazıcı oluşturulan katmanlar çerçevesinde, boş bir platforma her seferinde bir katmanı yazarak, tuğla örme örneğinde olduğu gibi tasarlanan modeli gerçeğe dönüştürmektedir (Horvath, 2014). Bu bağlamda, 3 boyutlu yazıc1, her seferinde bir kat oluşturmak suretiyle, nesne oluşturan bir araçtır. Bu yazıcıların kullandıkları malzemeler plastikten metale, çikolataya ve betona kadar farklılık göstermektedir (Horvath, Cameron ve Adrianson, 2015).

Günümüzde bildiğimiz şekliyle 3D baskının doğuşu, Chuck Hull'un, 3 boyutlu nesne oluşturmak için UV 1şı̆̆ı kullanan bir baskı yöntemi olan stereolitografiyi icat ettiği 1984 tarihidir (Williams, 2015). Üç boyutlu yazıcıların ilk kullanılmaya başlandığı yıllarda var olan yüksek maliyeti yavaş ama istikrarlı bir düşüş ivmesi içerisindedir. Bu durum dijital teknoloji ağı ile işlemlerini gerçekleştiren üç boyutlu yazıcıların kullanım alanın genişlemesini ve farklı sektörlerde kendisine yer bulmasını sağlamıştır.

Üç boyutlu yazıcıların kullanımı, endüstriyel alanda ve tüketici kullanımında olmak üzere temel olarak iki alanda genişleme imkânı bulmaktadır. Endüstriyel kullanım ağı içerisinde seri prototipleme, seri üretim, kütle özelleştirme, kütle halinde üretim, kıyafet tasarımı ve hobi alanlarında giderek yaygın hale gelmektedir. Endüstriyel alanda seri prototipleme amacıyla çalışan ve 1980'lerin başında ortaya çıkan üç boyutlu yazıcılar devasa boyutlara sahip iken, seri üretim amacına sahip olan üç boyutlu yazıcılar ise görece küçük boyutlardadır (Balcığlu, 2014). Tüketiciye yönelik kullanımda ise 2010 yılı üç boyutlu yazıcılar için milat niteliği taşımaktadır. Üç boyutlu yazıcılar için ücretsiz yazılım üretilmesini amaçlayan RepRap projesi ile üretilen yazılımlar sayesinde üç boyutlu yazıcıların fiyatlarında önemli bir düşüş yaşanmıştır. $\mathrm{Bu}$ sayede tüketici kullanımına açılımı hızlanmıştır (Hausman, 2013). Bireyler, çok yüksek maliyetler ödemek zorunda kalmadan kendi kişisel üç boyutlu yazıcılarına sahip olabilir hale gelmiş ve bu yazıcıları kendi istekleri doğrultusunda farklı alanlarda kullanabilir olmuştur. Bu durum dünya genelinde üç boyutlu yazıcılara olan ilginin artışını beraberinde getirmiştir.

Üç boyutlu yazıcıların, yazılım maliyetinin düşmesi sonucunda endüstriyel ve tüketiciye yönelik kullanımıyla birlikte eğitim ortamlarında da kullanılmaya başlandığ 1 görülmektedir. Düşük maliyetli üç boyutlu yazıcılar ile birlikte okul ortamlarında eğitim olanaklarını güçlendiren ve hızlı bir şekilde üretilebilen eğitim materyalleri üretilmektedir. $\mathrm{Bu}$ sayede matematikte üç boyutlu objelerin hacim ve alan gibi hesaplamalarında, coğrafyada yer şekillerinde, sanatta çeşitli eserlerin üretilmesinde, fende moleküllerin tasarlanmasında, müzikte müzik aletlerinin üretilmesinde üç boyutlu yazıcılar kendilerine kullanım alanı bulmaktadır (Lütolf, 2013). Bununla birlikte okullarda üç boyutlu yazıcılar sayesinde, öğrencilerin kendi şehirlerini yaratması, tarih öncesi varlıkların örneklerini canlandırması, dünyadaki önemli kültürel ve tarihi mekânların üretilmesi gibi öğrenci ve öğretmen yaratıcılığına bağlı olarak gerçekleştirilebilecek pek çok etkinlik ve proje olanağı bulunmaktadır (Leakey ve Dzambazova, 2013; Pietrosemoli, 2013).

Öğrencilere 3 boyutlu yazıcılar gibi yenilikçi teknolojileri sunmak, 21. yüzyıl becerilerini kazanma ve uygulama firsatı vermenin etkili yollarından biri olarak görülmektedir. Bilgiyi aktarmak ve kavramları öğretmek için doğrusal, iki boyutlu öğretim yöntemleri kullanmak yerine, elle tutulan üç boyutlu modeller sunarak öğrencilerin öğrenme deneyimlerini güçlendirmektedir. Bu noktada bazı eğitimciler, üretim ve endüstriye kıyasla eğitimde daha az değer taşıdıklarını belirtmektedirler. Ancak, bir 3 boyutlu yazıcı, programda öğrencinin merakını ve yaratıcılığını beslediği gibi öğrenme tutkularını da 
artırabilecektir (Cano, 2015). Bu nedenle 3 boyutlu yazıcıların avantajlarının yanı sıra, öğrenme-öğretme ortamlarında uygun biçimde kullanılabilmesi için teknik destek, yönetsel destek, yazılım ve donanım erişimi gibi okullara ait altyapı faktörlerinin uygun olması; öğretmen ve öğrencilerin bu teknolojiyi deneyimleme imkânına sahip olması ve bu konuda uzman bir ekip tarafından yerel desteğin sağlanıyor olması gerekmektedir (Demir Kuzu ve diğerleri, 2016).

3 boyutlu yazıcılardan elde edilecek modellerin sosyal bilgiler eğitimi açısından da önemli katkılar sağlayacağı düşünülmektedir. 3 boyutlu yazdırma sosyal bilgiler eğitimine FeTeMM (Fen, Teknoloji, Matematik, Mühendislik ) eğitimini entegre etmek amacıyla etkili bir yol olarak görülmektedir. 3 boyutlu modelleme ve baskı sosyal bilgiler dersinde, öğrencilerde eleştirel düşünme, problem çözme ve yaratıcılık becerilerini geliştirmek için yeni olanaklar sunabilecek, dinamik ve ilgi çekici eğitim deneyimleri için katalizörde olabilecektir (Cano, 2015). Bu yazıcılar yeni öğrenme materyalleri oluşturulmasında öğretmenlere katkı sağlayacağı gibi öğrencilerin kendi modellerini oluşturarak yazdırmalarını sağlayabilecek ve böylelikle teknolojiyi etkili kullanma becerilerinin gelişimine de katkı sunabilecektir. Ayrıca sosyal bilgiler dersinde çeşitli disiplinlerin öğretiminde 3 boyutlu yazıcılar yeni araçlar sağlayabilecektir. Örneğin sanal müze gezilerine alternatif olarak öğrenciler, geçmişten gelen fosiller, aletler ve diğer eserlerin baskısını yaparak sınıflarında inceleyebileceklerdir. Öğrenciler icat ve buluşları, nesli tükenmiş canlıları, savaş alanlarını tasarlayarak veya internetten bularak yazdırabilecek ve daha somut öğrenmeler gerçekleştirebileceklerdir. Öğrenciler coğrafya konularında dünyadaki herhangi bir alanın 3 boyutlu modellerini oluşturup yazdırabileceklerdir. 3 boyutlu yazıcıların sunduğu tüm bu faydaların sağlanabilmesi ise bu konudaki bilgi ve deneyimlerin arttırılmasını ve çeşitli araştırmalarla desteklenmesini gerekmektedir.

3 Boyutlu yazıcıların eğitim ortamlarında kullanımının henüz yeni olması nedeniyle bu alanda gerçekleştirilen çalışmalar sınırlıdır. Bu çalışmaların büyük bir çoğunluğunun yükseköğretim düzeyinde gerçekleştirildiği görülmekle birlikte ilk ve orta öğretimde de kimi çalışmalar gerçekleştirilmiştir. Gerçekleştirilen çalışmaların mühendislik eğitimi (Martin, Bowden ve Merrill, 2014; Golub, Guo, Jung ve Zhang, 2016; Lee, Shin ve Cho, 2015; Park, 2014).), robotik eğitimi (Hamidi ve diğerleri, 2017), özel eğitim (Buehler, Kane ve Hurst, 2014), anatomi eğitimi (Vaccarezza ve Papa, 2015), tıp eğitimi (Costello ve diğerleri, 2014), yer bilimi eğitimi (Horowitz ve Schultz, 2014), tasarım eğitimi (Greenhalgh ve Greenhalgh, 2016), fen eğitimi (Byun, Jo ve Cho, 2015), STEM eğitimi (Schaffhauser, 2013; Vanscoder, 2014; Straub, Berk, Nordlie ve Marsh, 2015; Taylor, 2016; Nichols, Schuster ve Ball 2016), matematik ve geometri eğitimi (Huleihil, 2017) gibi farklı alanlarda konumlandığı görülmektedir. Sosyal bilgiler eğitimine ilişkin ise sınırlı sayıda çalışmaya (Maloy, Kommers, Malinowski ve LaRoche, 2017) rastlanılmıştır. $\mathrm{Bu}$ çalışmada 4 ortaokuldaki sosyal bilgiler dersinde öğretmen ve öğrencilerin 3 boyutlu yazdırma teknolojisinin kullanımı incelenmiştir. Çalışma sonucunda öğretmen ve öğrencilerin başlangıçta, sosyal bilim kavramlarını temsil etmek için 3 boyutlu yazıcıdan alınan fiziksel nesneleri kullanma yollarını kestiremedikleri ancak daha sonra 3 boyutlu baskının olumlu yönlerinin farkına varıldığı; 3 boyutlu modelleme programlarının kullanımının oldukça zor olduğu; öğretmen (uzman) ve öğrenci (acemi) ilişkilerinin bu kullanım süresince tersine döndüğü; 3 boyutlu yazıcıların kullanımı ve içerik konusunda teknik uzmanlarla işbirliğinin önemli olduğu; bazı 
Soyuttan somuta, sanaldan gerçeğe: öğretmen adaylarının bakış açısıyla üç boyutlu ...

öğretmenlerin derslerinde 3 boyutlu yazıcı kullanmanın değeri ile ilgili düşüncelerinin olumlu yönde değiştirdikleri sonuçlarına ulaşılmıştır.

İlgili araştırmalar, pek çok alanın eğitiminde 3 boyutlu yazıcıların kullanımına yönelik çalışmaların artarak devam ettiğini göstermektedir. Sosyal bilgiler eğitiminde de 3 boyutlu yazıcıların kullanımına yönelik nicel ve nitel araştırmaların gerçekleştirilmesi alana katkı sağlayacaktır. Bu araştırmanın amacı, Sosyal Bilgiler Öğretmen Adaylarının (SBÖA) 3 boyutlu yazıcılar ve bu yazıcılar aracılığıyla alınan modellere ilişkin görüşlerini ve öğretmen adaylarının bakış açısıyla bu modellerin sosyal bilgiler dersine katkılarını belirlemektir. Berson ve Balyta (2004) teknolojide yaşanan gelişme ve değişimlerin sosyal bilgiler öğretmeni yetiştirme sürecinde de değiş̧iklikler yapılması gerekliliğini ortaya çıkardığını ve öğretmen adaylarının eğitimine teknolojinin öğrenmeyi ve öğretmeyi geliştirici yönde dâhil edilmesi gerektiğini belirtmektedirler. Bu kapsamda araştırmada elde edilecek bulgular neticesinde sosyal bilgiler öğretmenlerinin 3 boyutlu yazıcılar konusunda daha bilgili ve deneyimli olarak yetiştirilmelerine yönelik öneriler getirilecektir. Araştırmanın genel amacı kapsamında yanıt aranan sorular ise şunlardır:

1- SBÖA'larının, 3 boyutlu yazıcılar hakkındaki genel görüşleri nelerdir?

2- SBÖA'larının, 3 boyutlu yazıcılara ilişkin önceki ders öncesi deneyimleri nelerdir?

3- SBÖA'larının, 3 boyutlu yazıcılar ve bu yazıcılar aracıllğıyla alınan modellerin sosyal bilgiler dersine katkıları hakkındaki görüşleri nelerdir?

4- SBÖA'larının, göre 3 boyutlu yazıcılar ve bu yazıcılar aracılığıyla alınan modellerin sosyal bilgiler dersinde kullanım alanları nelerdir?

5- SBÖA'larının, geliştirdikleri ders planında hangi 3 boyutlu modeli/leri kullanmışlardır?

6- SBÖA'larının, ders planı için 3 boyutlu model ararken/geliştirirken ne tür sorunlarla karşılaşmışlardır?

7- SBÖA'larının, 3 boyutlu yazıcılar konusunda daha fazla bilgi, beceri ve deneyim elde edebilmelerine yönelik önerileri nelerdir?

\section{YÖNTEM}

\subsection{Araştırma Modeli}

Sosyal Bilgiler Öğretmen Adaylarının (SBÖA) 3 boyutlu yazıcılar ve bu yazıcılar aracılı̆̆ılyla alınan modellere ilişkin görüşlerini ve bu modellerin sosyal bilgiler dersine katkılarını incelemeyi amaçlayan bu araştırmada nitel araştırma yaklaşımı benimsenmiştir. Çalışmada nitel araştırma yaklaşımına dayalı olarak olgubilim deseni kullanılmıştır. Olgubilim, bireylerin herhangi bir kavram ya da olguya ilişkin algılarını, görüşlerini ve deneyimlerini incelemeyi amaçlamaktadır (Creswell, 2007).

\subsection{Katılımcılar}

Araştırmanın çalışma grubunun belirlenmesinde amaçlı örnekleme yöntemlerinden ölçüt örneklemeden yararlanılmıştır. Ölçüt örnekleme yönteminde araştırmanın amacına göre bir dizi ölçüt belirlenir ve çalışma grubu bu ölçütlere uygun kişiler tarafindan oluşturulur (Yıldırım ve Şimşek, 2005). Bu araştırmada çalışma grubu bir devlet üniversitesinde Sosyal Bilgiler Öğretmenliği Programı’nda 2015-2016 güz yarıyılında öğrenim gören ve 
"Sosyal Bilgiler Ders Kitabı İncelemeleri" dersinde 3 boyutlu yazıcı ile ilişkilendirilmiş ders planı hazırlayan 20 gruptan 1'er üye olmak üzere 20 (11 erkek 9 kadın) öğretmen adayından oluşmaktadır. Sosyal Bilgiler Öğretmenliği Programında teknoloji destekli etkinliklerin bütünleştirilebileceği derslerden biri olması nedeniyle bu ders tercih edilmiştir. Araştırma kapsamında, dönem başında "Sosyal Bilgiler Ders Kitabı İncelemeleri” dersini alan 63 öğrenciye 3 boyutlu yazıcılar ve sosyal bilgiler eğitiminde kullanımına yönelik 2 saatlik tanıtım yapılmış, sınıf 3 ve 4 'erli 20 gruba ayrılarak gruplardan, 3 boyutlu yazıcıların ve bu yazıcılardan alınan modellerin kullanıldığı bir ders planı hazırlamaları istenmiştir. Böylelikle bütün öğretmen adaylarının üç boyutlu yazıcılarla karşılaşması ve ders planı hazırlayarak deneyimlemeleri sağlanmıştır. Daha sonra her gruptan 1 öğrenci ile olmak üzere toplam 20 öğrenci ile yarı yapılandırılmış görüşmeler gerçekleştirilmiştir. Ayrıca hazırlanan 20 ders planı öğretmen adaylarından teslim alınarak analize hazır hale getirilmiş̧ir.

\subsection{Verilerin Toplanması ve Veri Toplama Araçları}

Araştırmada veri toplama aracı olarak yarı yapılandırılmış görüşme ve döküman analizi formundan yararlanılmıştır. Yarı yapılandırılmış görüşme tekniği, yapılandırılmış görüşme tekniğinden daha esnektir. Araştırmacı bu teknikte, önceden sormayı planladığı soruları içeren görüş̧me formunu hazırlar. Bunun yanında görüşmenin akışına bağlı olarak değişik yan ya da alt sorularla görüşmenin akışını etkileyebilir. Görüştüğü kişinin yanıtlarını ayrıntılandırılmasını sağlayabilir (Türnüklü, 2000).

Yarı yapılandırılmış görüşmeler için hazırlanan yarı yapılandırılmış görüşme formunun oluşturulmasında öncelikle alan yazından yararlanılmış, taslak form hazırlanarak uzman görüşleri alınmıştır. Gerekli düzenlemelerin yapıldığı formun pilot uygulaması 3 sosyal bilgiler öğretmen adayı üzerinde gerçekleştirilerek son biçimi verilmiş ve uygulamaya hazır hale getirilmiştir. Görüşmelerde öğretmen adaylarına 3 boyutlu yazıcıların kendileri için ne ifade ettiği, bu konudaki deneyimleri, 3 boyutlu yazıcıların sosyal bilgiler dersine katkıları ve sosyal bilgiler dersinde kullanım alanları, süreçte yaşadıkları sorunlar ve önerilere ilişskin 10 soru sorulmuştur. Görüşmeler 2015 yılının Kasım ve Aralık aylarında gerçekleştirilmiştir. Görüşmeler yaklaşık olarak 20 ile 30 dakika sürmüştür. Görüşmelerde alınan ses kayıtları bilgisayar ortamında yazılı hale getirilmiştir.

\subsection{Verilerin Analizi}

Araştırma kapsamında elde edilen verilerin analizinde tümevarımsal analiz yaklaşımı benimsenmiştir. Araştırmanın inandırıcılığının artırılması amacıyla veri analiz sürecinde görüşme verilerinin \%20'lik bölümü bir başka uzman tarafından kodlanmıştır. Konu uzmanının yaptığı kodlama analiz çeşitlemesi olarak adlandırılmaktadır (Patton, 2002; Glesne, 2012). Veriler öğretmen adaylarının görüşlerinden doğrudan alıntılarla desteklenerek sunulmuştur. Öğretmen adaylarının görüsslerine yapılan atıflarda kendilerine verilen kod isim kullanılmıştır. Bu kapsamda katılımcılar K1, K2, K3 ...K20 şeklinde kodlanmış, katılımcının erkek yada kadın olduğunu belirtmek amacıyla erkekler için=E, kadınlar için=K harfi, katılımcı numarasının sonuna eklenmiştir. (Örneğin $\mathrm{K} 1 \mathrm{E}=$ Kat1lımc11Erkek, K2K= Kat1lımc12Kadın). 
Soyuttan somuta, sanaldan gerçeğe: öğretmen adaylarının bakış açısıyla üç boyutlu ...

\section{BULGULAR}

\subsection{Sosyal Bilgiler Öğretmen Adaylarına Göre 3 Boyutlu Yazıcılar}

Bu tema altında 3 Boyutlu yazıcıların SBÖA'ları için ne ifade ettiği ve bu yazıcılara ilişkin önceki deneyimlerine yer verilmektedir. Araştırma kapsamında görüşülen SBÖA'larının 3 boyutlu yazıcılara ilişkin görüşleri tekrarlanma sıklığına göre "somutluk", "materyal üretimi”, "devrimsel bir teknoloji”, "kolaylık”, “ üçüncü boyut" ve "dokunma" biçimindedir.

\subsubsection{Somutluk}

SBÖA'larının 3 boyutlu yazıcılar için en fazla somutluk ifadesini kullandıkları görülmektedir. Bu kapsamda 3 boyutlu yazıcılar ve bu yazıcılar aracılığıyla alınan modellerin çocuklar için soyut olan bilgileri, kavramları, görselleri, ulaşılamayacak nesneleri somutlaştırdığını ve bu nedenle de ilk olarak akıllarına somutlaştırmanın geldiğini belirtmektedirler. Örneğin K6K nolu öğretmen adayı "Öğrencilere gerçekte gösteremeyeceğimiz şeyleri bu 3 boyutlu modellerle sinıfa getirerek, bunları resimlerle de destekleyerek ögrencilere sunabiliriz. Böylece öğrenciler onları daha çok soyut bir biçimde düşünmezler, daha çok görürler ve somut bir biçimde görürler." biçiminde görüşünü ifade etmiştir. K18K nolu öğretmen adayı da "Benim için somut yani somutlaştırmayı ifade ediyor. Daha çok ögrencinin aklında kalmasını sağlayacak bir materyal olduğunu düşünüyorum” ş̧eklindeki görüşüyle somutlaştırmaya atıfta bulunmuş ve 3 boyutlu yazıcılar ve bu yazıcılar aracılığıyla alınan modellerin bunu sağlayacak birer materyal olduğunu ifade etmiştir.

\subsubsection{Materyal üretim aracı}

Öğretmen adaylarının vurguladıkları diğer önemli bir nokta 3 boyutlu yazıcıların birer materyal üretim aracı olmasıdır. Bu kapsamda K11K nolu öğretmen adayı " $\ddot{U} c ̧$ boyutlu yazıcı öncelikle kullanışlılık açısından oldukça verimli elimizde olmayan ürünleri de çıktı sayesinde elde edebiliyoruz" şeklinde; K20E nolu öğretmen adayı da "Öğretmenlik için iyi özellikle materyal konusunda sıkıntı yaşadığımız dönemlerde okulların özellikle, iyi bir yöntem. Sadece bir tane modeli yazıcıyla da öğretmenlerin istedikleri gibi yapılabilir diye düşünüyorum” biçiminde bu konudaki görüşlerini ifade etmişlerdir. Öğretmen adaylarının ifadelerinde görüldüğü gibi 3 boyutlu yazıcılar öğrenme-öğretme sürecini destekleyecek materyallerin kullanışlı bir biçimde üretilebileceği araçlar olarak görülmektedir.

\subsubsection{Devrimsel bir teknoloji}

Öğretmen adaylarının bazıları 3 boyutlu yazıcıları devrimsel bir teknoloji olarak nitelendirmektedir. Örneğin K14E nolu öğretmen adayı "Ben bu dersten önce hiçbir şekilde böyle bir şeyin, teknolojinin varlı̆̆ından habersizdim. Gerçekten devrimsel bir teknoloji olduğunu düşünüyorum. Çünkü, derslerimizde 3 boyutlu modelleri kullanarak dersi daha etkili hale gelmesini săgllyor bunlar" şeklinde; K8E nolu öğretmen adayı da "Bunlarla ilgili çok fikrim yoktu dersle birlikte oldu. Daha önceden duymamıştım da kendim eve gidince araştırma yaptım fiyatlarını. Aslında sizin de dediğiniz gibi gerçekten bu sanayi devrimi gibi olabilir. Öğretimde çok iyi kullanılabilir materyal tasarımlarında ya da başka şeylerde" biçiminde bu konudaki görüşlerini dile getirmişlerdir. Bu noktada 
öğretmen adaylarının özellikle öğrenme-öğretme süreci açısından 3 boyutlu yazıcıları devrimsel bir teknoloji olduğunu düşündükleri görülmektedir.

\subsubsection{Kolaylık}

Öğretmen adayları 3 boyutlu yazıcıları ayrıca "kolaylık" biçiminde tanımlamışlardır. Örneğin K5K nolu öğretmen adayı "Aslında ilk önce kolayllk geliyor yani hayatımızı kolaylaştıran bir şey. Aslında aklımıza gelen her an ihtiyacımı olan bir şeyi iki dakika içerisinde yazdırabilmek bence büyük kolaylık. "şeklinde görüşünü dile getirmiştir.

\subsection{6. Üçüncü boyut}

Öğretmen adaylarının bir diğer vurgusu ise "3. boyut" olmuştur. Bu yazıcıların 3.boyutuna atıfta bulunan K3E nolu öğretmen adayı "3 boyutlu yazıcı resmin daha çok heykele dönüşmüş hali gibi düşünüyorum. Daha kolay daha net görünür. Çünkü resimde her tarafin göremiyorum ama 3 boyutlu yazıcıda her tarafinı görebiliyorum ordan çıkan modellerde." biçiminde bu durumu açıklamıştır.

\subsubsection{Dokunma}

Bir diğer atıfta bulunulan tema ise "dokunma"dır. Özellikle 3 boyutlu yazıcılardan elde edilen modellerin dokunularak öğrenmeyi gerçekleştirmesine değinen K1E nolu öğretmen adayı görüşünü "Bu konudaki genel görüşlerim 3 boyutlu yazıcı denilince daha çok algllama, yetenek bakımından bakiyorum. Ne bileyim bir şeyi daha çok gözlerimle daha iyi hissedebiliyorum yani. Elimle dokunabilince daha iyi algilayabiliyorum. Yani 3 boyutlu kavramı benim için bunu ifade ediyor. " biçiminde dile getirmiştir.

Yukarıda görüldüğg̈ gibi öğretmen adayları 3 boyutlu yazıcıları özellikle öğrenmeöğretme sürecindeki rolü çerçevesinde ele alarak, somutlaştırmayı kolaylaştırıcı materyal üretimini sağlayan, devrim niteliğindeki teknolojik bir araç olarak görmektedirler. Öğretmen adaylarının ders öncesinde 3 boyutlu yazıcılarla ilgili deneyimlerine bakıldığında ise yarısından fazlasının ilk defa bu derste 3 boyutlu yazıcılardan haberdar oldukları, çok az bir bölümünün ise televizyon ve internet haberlerinde ya da teknoloji marketlerde görmekle birlikte ilk defa uygulama şansı buldukları görülmektedir. Ayrıca, öğretmen adayları bu teknolojinin kendilerinde heyecan ve şaşkınlık yarattığını ifade etmişlerdir. Öğretmen adaylarının 3 boyutlu yazıcılar ile ilgili ders öncesindeki deneyimlerinden bazılarına aşağıda yer verilmektedir.

"Yani çok şaşırdım karşılaştığım zaman. İlk başta derste bahsetmiştiniz 3 boyutlu yazıcıdan. Ben zannediyordum genelde kağıt falan çıkartıyor yazıcılar, hiç aklıma yatmamıştı. Çok tuhaf bir his." (K14E)

"Ü̧̧ boyutlu yazıcı ve üç boyutlu model kavramını ilk defa bu dersten öğrendim. Dersle beraber görmüş oldum. Ü̧ boyutlu yazıcı deyince aklıma çok bir şey canlandiramiyordum ta ki derste görünceye kadar." (K17K)

"İşin açıkçası 3 boyutlu yazıcıyı ilk defa ben televizyonlarda falan duymuştum ama böyle birebir inceleme imkanım olmadı." (KIE)

“ilk defa 2014'teydi teknoloji marketinde gezerken orda gördüm çalışlyordu. Bir kişinin resmini koymuşlardı onun heykelini çıkartıyordu. Çok hoşuma gitmişti. Buradan tarihi eserler falan çıkarsak derste güzel olurdu, o şekilde düşünmüştüm.", $(K 3 E)$ 
Soyuttan somuta, sanaldan gerçeğe: öğretmen adaylarının bakış açısıyla üç boyutlu ...

\subsection{Sosyal Bilgiler Dersine 3 Boyutlu Yazıcıların Katkıları}

Araştırma kapsamında görüşülen SBÖA'larının 3 boyutlu yazıcıların sosyal bilgiler dersine katkılarına ilişkin görüşleri tekrarlanma sırasıyla "somutlaştırma", "kalıcı öğrenme", "dokunarak öğrenme”, "dikkat çekme ve güdülenme” ile "müze ve ders diş1 gezileri sınıfa getirme" biçimindedir.

\subsubsection{Somutlaştırma}

Öğretmen adaylarının yarısından fazlasının 3 boyutlu yazıcılar ve bu yazıcılardan elde edilen modellerin sosyal bilgiler dersinde "somutlaştırma"yı sağlayacağını ifade ettikleri görülmektedir. Bu konudaki bazı öğretmen adaylarının görüşlerine aşağıda yer verilmektedir:

"Şöyle söyleyeyim, somut bir şey olduğu için elimde. Soyut da önemli bir şey ama daha böyle sosyal bilgiler öğretmenliği programı için kazanımlar için somut deliller bizim için çok önemli . O yüzden 3 boyutlu çıktı çok iyi oldu.” (K13E)

“Çok büyük katkıları olacă̆ını düşünüyorum ben bu konuda. Çünkü biz 5. sınıflara girdiğimizde soyut kavramları da öğretmemiz gerekecek ama somutlaştırmamız gerekecek. Bunlarl öğrencileri bu şekilde somut şeyleri ellerine verdiğimizde daha iyi ögrenebileceklerini düşünüyorum.” (K17K)

“Sosyal bilgilere katkısı kesinlikle olacağını düşünüyorum. Çünkü özellikle ilkokul düzeyinde ögrencilerin soyut düşünceyi kazanana kadar somutlaştırarak anlattığımız için bu materyal olarak kullandığımızda etkisi olacă̆ını düşünüyorum açıkçası.” (K9K)

Yukarıdaki ifadelerde de görüldüğü gibi öğretmen adayları ilk ve orta öğretimdeki öğrencilerin gelişimsel özellikleri doğrultusunda 3 boyutlu yazıcılardan elde edilen modellerin somut öğrenmeyi sağlayacağını belirtmekte ve bu nedenle önemli bir teknoloji olarak ele almaktadırlar.

\subsubsection{Kalıcı öğrenme}

Öğretmen adaylarının dile getirdiği bir diğer etki ise kalıcı öğrenmelerin sağlanması olmuştur. $\mathrm{Bu}$ noktada özellikle sosyal bilgiler içerisindeki disiplinlerden örneklendirmeler yapan öğretmen adayları görsellik ve somutlaştırmanın öğrenmede kalıcılığını arttıracağını ifade etmişlerdir. Örneğin K14E nolu öğretmen adayı bu konudaki görüşünü "Yeryüzü şekillerinin anlatılmasında ben lisedeyken hep normal anlatır geçerlerdi. Böyle bir teknoloji olsa ben bir falezin, peri bacasının ve ya bir kiyı tipinin, Ria klyı tipinin şeklini görsem onu unutmazdım. Kalıcılığın sağlanmasında çok önemli diye düşünüyorum." şeklinde dile getirmiştir. K1E nolu ögretmen adayı da görüşünü şu sözlerle açıklamıştır:

"Sosyal bilgiler zaten disiplinler dersi, disiplinlerin bütünleştirilmesi, disiplinler arası bir ders. Bunun içinde coğrafyası var tarihi var, bunu sürekli sözel ifadelerle anlatırken zorlanıyoruz. Öğrenciye Türkiye’nin yüksekliğini göstermek istiyoruz, Türkiye'nin dăglarını göstermek istiyoruz, Misır piramidini göstermek istiyoruz. Bunu ögrenciye anlatıyorsun veya söylüyorsun, görselle gösteriyorsun, kalabildiği bir yere kadar. Ama onu tuttuğunda 3 boyutlu bir biçimde 4 bir yandan alttan üstten gördügünde daha kalıcı olabiliyor." (KIE) 


\subsubsection{Dokunarak öğrenme}

Öğretmen adayları üç boyutlu yazıcılar aracılı̆̆ıyla elde edilen modellerin özellikle birden fazla duyu organını işe koşulmasını sağladığını ve eksikliği hissedilen dokunma duyusunun bu modeller aracilığıyla öğrenme-öğretme sürecine dâhil edilebildiğini ifade etmektedirler. Bu bağlamda görüşlerini ifade eden K1E nolu öğretmen adayı "Bir şeyi okumak vardır bir şeyi görmek, tutmak, hissetmek vardır. 3 boyutlu yazıcılar bize görme yerine tutmayı ve dokunmayı hissettirdiği için daha çabuk anlamlandirabiliyorum daha perspektif bir açıdan daha farklı açılardan bakabiliyorum." şeklindeki görüşüyle bu durumu desteklemekte ve görme duyusunun yanı sıra dokunma duyusunun işe koşulmasına atıfta bulunmaktadır. Ayrıca bu durumun o kavrama ya da konuya ilişkin perspektif oluşturmasına yardımcı olabileceğini ifade etmektedir. K19K nolu öğretmen adayı da "Ders planında şey yapmıştık, piramitler, o piramitlerin içine sanal tur düzenledik. Çocuk elinde var olan şeyin içindekilerin nasıl olduğunu görüyor. Hem dışsal olarak hem içsel olarak gözünde tamamen canlaniyor, bir de dokunuyor o da daha etkili oluyor. " biçimindeki görüşüyle son yıllardaki sanal gezilerin 3 boyutlu yazıcılar aracıyla somutlaşacağını ve 3 boyutlu yazıcıların sanal gezilerdeki dezavantajı kapatabileceğini belirtmektedir.

\subsubsection{Dikkat çekme ve güdüleme}

Öğretmen adayları, 3 boyutlu yazıcılar ve bu yazıcılar aracılığılla alınacak modellerin sosyal bilgiler dersinde öğrencinin güdülenmesini ve dikkatinin çekilmesini sağlayacağını ifade etmektedirler. Öğretmen adayları bunun nedenlerini ise derse çeşitlilik katmasına, dersi monotonluktan kurtarmasına ve meraklarını çekmesine bağladıkları görülmektedir. K13E nolu öğretmen adayı "Çeşitlilik kattyor. Yani normal monotonluktan çıkarttyor ögrrencileri, dikkat çekme konusunda, güdüleme konusunda öğrencileri etkileyebilir" şeklindeki görüşüyle bu durumu açıklamaktadır. K18K nolu öğretmen adayı ise "Kendimde uyguladım gördüğüm için öğrencilerde bir merak uyandirtyor, güdülenmeyi sağllyor, derse konsantre olmasını sağllyor. Acaba sonradan ne çıkacak diye merakı uyandirlyor öğrencilerde. Somutlaştırma açısından, güdüleme açısından, merak uyandırma açısından, öğrencinin dikkatini çekme açısından kesinlikle." biçimindeki görüşüyle bu derste öğrendiklerini staj okulunda denediğini ve öğrencilerin dikkatini çekmede ve motive olmalarını sağlamada etkili olduğunu belirtmiş̧ir.

\subsubsection{Müze ve ders dışı gezileri sınıfa getirme}

Öğretmen adayları 3 boyutlu yazıcıların özellikle müze ve ders dışı geziler kapsamında gidilemeyen yerlerdeki eser ve nesnelerin sınıfa getirilmesi anlamında katkıları olacağını belirtmektedir. Bu bağlamda K19K nolu öğretmen adayı "Bence en fazla Sosyal bilgilere katkısı olur. Çünkü tarihsel olarak görseller çok fazla var ve her birini gidip tek tek gezme imkânı yok ama bu yazıcılar sayesinde çocuğun gezmeden eline veriyorsunuz bunu, daha fazla katklst var." biçiminde görüşünü dile getirmiştir. K3E nolu öğretmen adayı aynı biçimde "Modeli gösteriyoruz internet üzerinden, heykel olarak çıkartabilirsek ögrenci onu daha net görebilir, eline alabilir, her tarafindan inceleyebilirler. Her yerde müze gezisi yapılamıyor. Nemrut dağı, Sümela. Bunların 3 boyutlu küçük modellerini çıkartırsak ögrenci en azından görüss sahibi olur" ş̧eklindeki görüşüyle bu durumu desteklemektedir. K20E nolu öğretmen adayı da "Bizim ülkemizde tarihi eser, kültürle ilgili çok yer var. Ancak okulların maddi destek vermemesinden ötürü 
Soyuttan somuta, sanaldan gerçeğe: öğretmen adaylarının bakış açısıyla üç boyutlu ...

böyle yerleri gezi görmek imkânsız oluyor. Köy okulunda okumuştum ilköğretimi. Yetersizlikten gezilere gidemezdik. Gidemeyen ögrenciler için bunların birebir kopyası olması iyi bir yöntem olacak. ” biçimindeki görüşüyle 3 boyutlu yazıcıların müze ve ders dışı gezilere katkısına ilişkin görüşlerini dile getirdiği görülmektedir. Bu kapsamda sosyal bilgiler öğretmen adaylarına göre 3 boyutlu yazıcılar ve bu yazıcılar aracılığıyla elde edilen modeller müzeleri ve sosyal bilgiler kapsamında gezilmesi gereken yerleri sınıfa ve okula getirme potansiyeli taşımaktadır.

\subsection{Sosyal Bilgiler Dersinde 3 Boyutlu Yazıcıların Kullanım Alanları ve Öğretmen Adaylarının Kendi Ders Planlarında Kullandıkları Modeller}

Sosyal bilgiler öğretmen adaylarının 3 boyutlu yazıcılar ve bu yazıcılar aracılığıyla alınan modellerin sosyal bilgiler dersinde kullanım alanlarına ilişkin görüşlerine bakıldığında "tarih" ve "coğrafya" konularının ön plana çıktığı saptanmıştır. Sosyal bilimlerin diğer disiplinlerindeki kullanıma ilişkin görüş ifade edilmemiştir.

Öğretmen adayları 3 boyutlu yazıcılar ve bu yazıcılardan elde edilecek modellerden, tarihsel konuların öğretiminde özellikle "tarihi yapılar", "tarihi eser ve araçlar"ın kullanımında yararlanılabileceğini ifade etmektedirler. Örneğin K3E bu konudaki görüşlerini "Sümela Manastırı dă̆ın içini oymuş diyoruz. Öğrenci bunu hayal ediyor, aslında 3 boyutlu modeli dağın yamacına yapılmış şeyi o şekilde görürse, kendisi görmüş kadar olur." biçiminde açıklamaktadır. K6K 'da "Sosyal Bilgilerde özellikle, bu kültürel özelliklerimiz dediğimiz bazl yapılar var. Öğrencilerin gidip görmesi o ünite için çok zordur ama ögretmen bir Efes-Antik Kentini ya da biz Bandırma Vapuru'nu çıkarttık. Bunları direkt sınıfa getirir ve ögrencinin görmesini sağlar.” şeklinde görüşünü açıklamaktadır. K13E nolu öğretmen adayı da "Tarih konusunda örneğin, eski çağlara ait materyaller o baltalar olsun bizzat çocuğun onla karşılaşması resimle değil de onu eline alıp incelemesi daha çok katkı sağlayacaktır." biçimindeki görüşüyle sosyal bilgilerde 3 boyutlu yazıcıların tarihsel kullanım alanlarını ve faydalarını ifade ettiği görülmektedir.

Öğretmen adayları, coğrafya konularının öğretiminde 3 boyutlu yazıcılardan, özelikle yeryüzü şekillerinin öğretiminde ve haritaların üretiminde yararlanılabileceğini belirtmektedirler. Öğretmen adaylarının bu konudaki görüşlerini geçmiş yaşantılarından örneklerle açıkladıkları görülmektedir. K18K nolu öğretmen adayı da "Coğrafya alanında kullanılabilir. Özellikle bence en çok da coğrafya alanında kullanılır baskın olarak. Yapılan yapıtlar olsun, doğa şekilleri, dağlar, ovalar bunlar çok somutlaştırllabilir." biçimindeki görüşüyle bu durumu desteklemektedir. Öğretmen adayları, 3 boyutlu yazıcıların ayrıca harita üretiminde kullanılabileceğini ve bu durumun sosyal bilgiler dersine önemli katkılar sağlayacağını ifade etmişlerdir. K17K nolu öğretmen adayı bu konudaki görüşünü "Benim yapacağım çalışmada kabartma haritası kullanımında ögrencilere kabartma haritası yaptırlması gerekiyor kazanımlardan birinde. Öğrencilere göstereceğim bu üç boyutlu modelle onların daha iyi yapabileceklerini düşünüyorum.” biçiminde dile getirmiştir. Aynı biçimde K3E nolu öğretmen adayı da, "Coğrafya derslerinde de faydalı. Türkiye haritasının 3 boyutlu modeli ya da bu bölgelerin 3 boyutlu modellerinin çıkartabiliriz ya da bir dünya modeli. Dünya modelleri var da her yerde yoktur. Onları çıkartabiliriz coğrafya derslerinde." şeklindeki görüşüyle ulaşılamayan haritaların ve dünya modellerinin üç boyutlu yazıcılar aracılığıyla elde edilebileceğini vurgulamıştır. 
Sosyal bilgiler öğretmen adaylarının kendi ders planlarında kullandıkları ve 3 boyutlu yazıcıdan çıkarılan modellere Tablo 1'de yer verilmiştir.

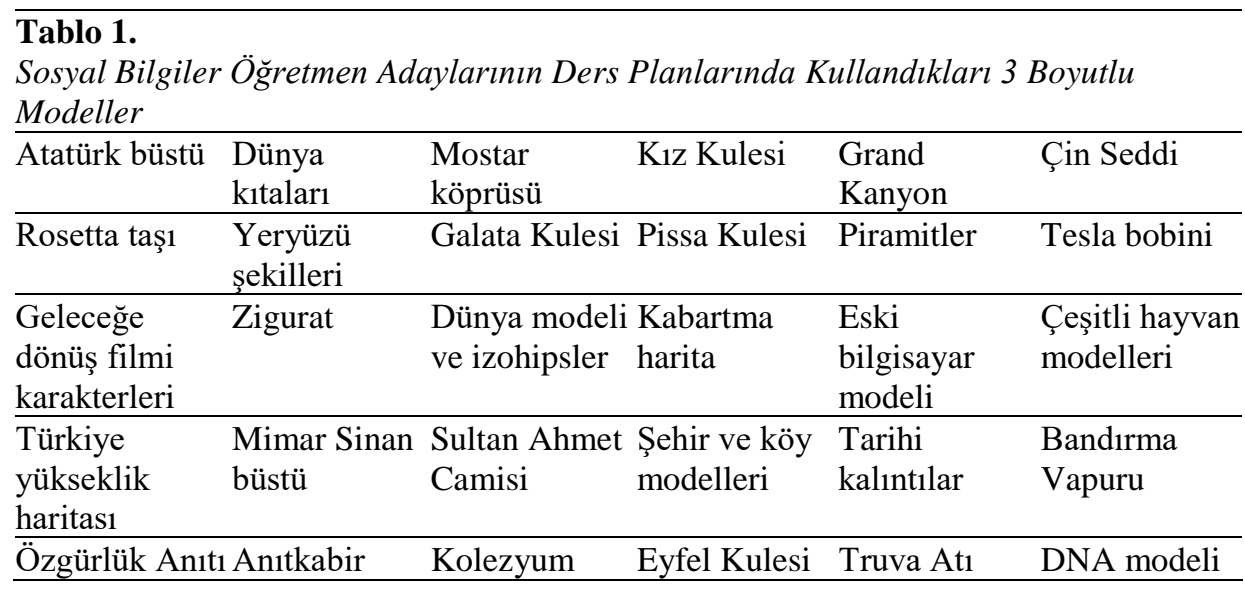

Sosyal bilgiler öğretmen adaylarının kullandıkları modellerin 3 boyutlu yazıcıdan alınan çıktılarına ilişkin görsellerden bazılarına Resim1, Resim2, Resim3, Resim4, Resim5 ve Resim6'da yer verilmektedir.

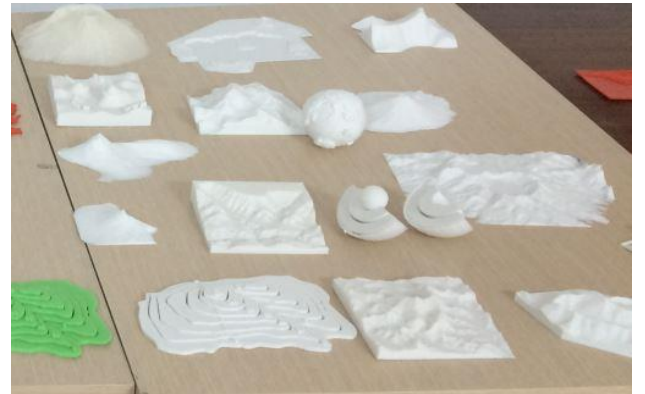

Resim 1. Yer yüzü şekilleri

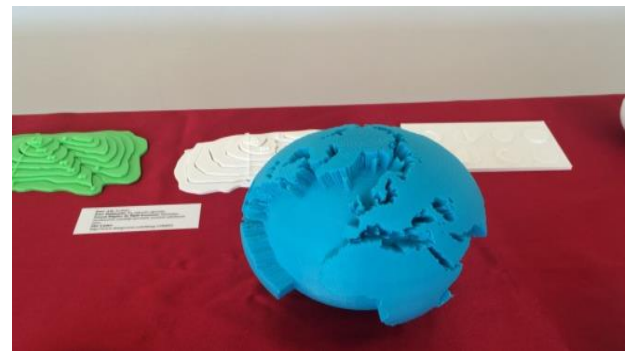

Resim 3. İzohipsler ve dünya karalar modeli

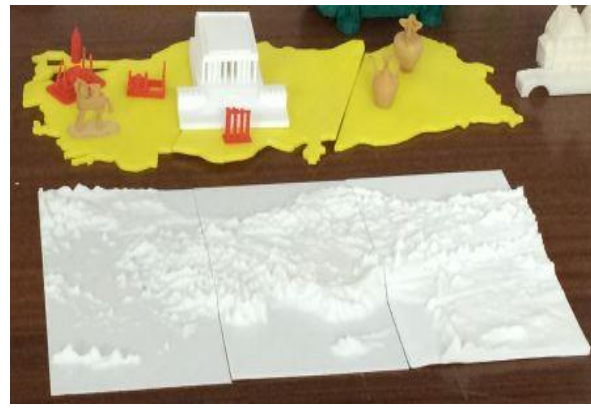

Resim 2. Anıtkabir, Türkiye kabartma haritas 1

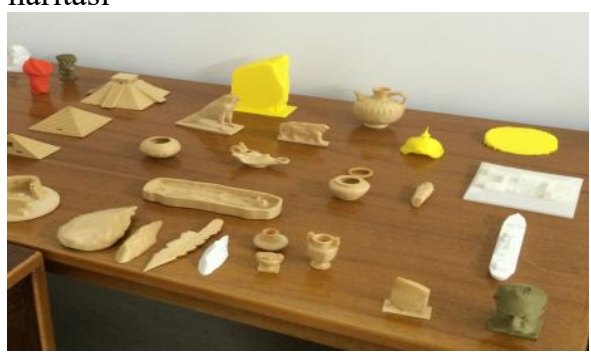

Resim 4. Atatürk büstü, Bandırma Vapuru ve Tarihi eserler 


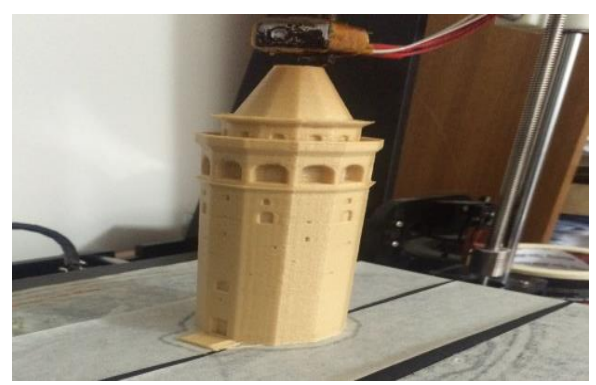

Resim 5. Tarihi yapılar (Galata Kulesi)

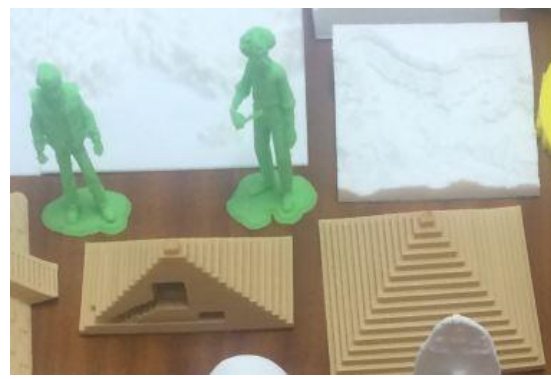

Resim 6. Piramitler ve Geleceğe Dönüş Filmi karakterleri

Öğretmen adaylarının ders planlarında kullandıkları modellere bakıldığında genellikle tarih ve coğrafya disiplinleri ile ilişkili olduğu yalnızca bir veya iki modelin bilim teknoloji ve ekonomi ile bağlantılı olduğu görülmektedir. Bu modellerin seçilme nedenleri incelendiğinde ise öncelikle kazanımla ilişkili olmaları, kolay ulaşabilmeleri ve öğrenmeyi kolaylaştırıcı rol üstleneceğini düşünmeleridir. Öğretmen adaylarının model seçimi konusundaki görüşlerinden bazılarına aşağıda yer verilmiştir.

“Bu modeli seçmemde Türkiye'yi anlatırken beşeri anlamda anlatıyoruz. Türkiye'yi anlatırken coğrafi anlamda anlatıyoruz. Bunları anlatmak için Türkiye’nin yer şeklini göstermek zorundayız. Bu modeli neden seçtim, öğrenciler daha iyi görebilmesi, kavrayabilmesi için, daha iyi hissedebilmesi için.” (K1E, Türkiye yükseklik haritasl)

“Bizim ders planında kullandığımız yeryüzü şekilleriydi. Kazanımdan yola çıkarak bunu belirledik. Çevresindeki doğal ve beşeri unsurları tanıması açısından bunu tercih ettik." (K11K, Yeryüzü şekilleri)

"Zigguratları seçtik. Bunu seçmemizin sebebi de kazanımımız ve konumuz üretimle alakalıydı.” (K7E, Ziguratlar)

"Bandırma vapurunu kullandık. Bandırma vapuru milli uyanışta güzel bir örnek olacă̆ını düşündük simgesel olarak.” (K10K, Bandırma Vapuru)

“Çünkü daha akılda kalıcı karşılaştırma yapılmasını istedik biz ögrrencilerden günümüzdeki bir bilgisayarla.” (K5K, eski bilgisayar modeli)

Sosyal bilgiler öğretmen adaylarının 3 boyutlu yazıcılardan aldıkları modelleri kullandıkları ders planlarındaki kazanımlara Tablo 2'de yer verilmiştir:

\section{Tablo. 2}

Sosyal Bilgiler Öğretmen Adaylarının 3 Boyutlu Yazıcılardan Aldıkları Modelleri Kullandıkları Kazanımlar

4. sinıf kazanımları

- Çevresinde gördüğü doğal ve beşerî unsurları ayırt eder.

- Kullandığı teknolojik ürünlerin zaman içindeki gelişimini kavrar.

- Millî Mücadele'nin kazanılmasında ve Cumhuriyetin ilânında Atatürk'ün rolünü fark eder. 
Tablo. 2 devamı

5. sinıf kazanımları

- Çevresindeki ve ülkemizin çeşitli yerlerindeki doğal varlıklar ile tarihî mekânları, nesneleri ve yapıtları tanır. (3 ayrı ders planında kullanılmıştır)

- Çeşitli ülkelerde bulunan ortak miras öğelerine örnekler verir. (3 ayrı ders planında kullanılmıştır).

- Buluş yapanların ve bilim insanlarının ortak özelliklerinin farkına varır.

- Yaşadığı bölgedeki ekonomik faaliyetleri fark eder.

- Yaşadığı bölgedeki ekonomik faaliyetler ile coğrafî özellikleri ilişkilendirir. 6. sinif kazanımları

- Farklı ölçeklerde çizilmiş haritalardan yararlanarak ölçek değiştiğinde haritanın değişen özellikleri hakkında çıkarımlarda bulunur (2 ayrı ders planında kullanılmıştır)

- Dünyanın farklı doğal ortamlarındaki insan yaşantılarından yola çıkarak, iklim özellikleri hakkında çıkarımlarda bulunur (2 ayrı ders planında kullanılmıştır)

- Konum ile ilgili kavramları kullanarak kıtaların, okyanusların ve ülkemizin coğrafi konumunu tanımlar.

- Örnek incelemeler yoluyla tarih öncesindeki ilk yerleşmelerden günümüze, yerleşmeyi etkileyen faktörler hakkında çıkarımlarda bulunur.

- Anadolu'da yaşamış ilk uygarlıkların yerleşme ve ekonomik faaliyetleri ile siyasal ve sosyal yapıları arasındaki etkileşimi fark eder.

- Tıp alanındaki buluş ve gelişmelerle insan hayatı ve toplumsal dayanışma arasındaki ilişkiyi fark eder.

- Bilimsel ve teknolojik gelişmelerin gelecekte ki yaşam üzerine etkilerine ilişkin yaratıcı fikirler ileri sürer.

- Görsel materyalleri ve verileri kullanarak dünyada nüfus ve ekonomik faaliyetlerin dağılışının nedenleri hakkında çıkarımlarda bulunur.

7. sinıf kazanımları

- Tarihten ve günümüzden örnekler vererek üretim teknolojisindeki gelişmelerin sosyal ve ekonomik hayata etkilerini değerlendirir.

8. sinıf kazanımları

- Mustafa Kemal'in Millî Mücadelenin hazırlık döneminde yaptığı çalışmaları, millî bilincin uyandırılması, millî birlik ve beraberliğin sağlanması açısından değerlendirir.

Yukarıdaki kazanımlar incelendiğinde öncelikle tarih ve coğrafya ile ilgili kazanımların ağırlıklı bir biçimde kullanıldığı görülmektedir. Bunun yanı sıra ekonomi ile bilim ve teknoloji bağlantılı kazanımlarda ders planlarında kullanılmıştır. En fazla kullanılan kazanımlar ise "Çevresindeki ve ülkemizin çeşitli yerlerindeki doğal varlıklar ile tarihî mekânları, nesneleri ve yapıtları tanır." ile "Çeşitli ülkelerde bulunan ortak miras öğelerine örnekler verir" olmuştur. Bunun nedeni ise internette bu kazanımlarla ilişkili daha fazla modelin yer almasıdır.

Öğretmen adaylarının 3 boyutlu yazıcılardan alınan modelleri ders planının hangi aşamasında kullanıldığına bakıldığında ise geliştirme bölümünün ön plana çıktı̆̆ görülmektedir. Örneğin K13E nolu öğretmen adayı ders planında dünya kültürel ögelerinin dersin geliştirme aşamasında kullanılacağı belirtilmiş bu durumu şöyle açıklamıştır: 
Soyuttan somuta, sanaldan gerçeğe: öğretmen adaylarının bakış açısıyla üç boyutlu ...

“Konu anlatıldıktan sonra sınıf grup çalışması yapılmak üzere beş gruba ayrılır. Her gruba önceden $3 d$ yazıcı ile çıkarılan ortak miras eserleri dağıtılır. Her gruba bir miras öğesi teslim edilir. Grup temsilcileri seçilir. Gruplara verilen 3D ortak miraslar Keops Piramidi, Eyfel Kulesi, Özgürlük Anıtı, Tac Mahal'dır. Gruplar bu $3 D$ eserleri inceleyerek özellikleri ile ilgili temalar çıkartmaları istenir. Bu temalar grup başkanları aracılığıyla sınıfta sunulur ve eser hakkında öğrenciler tarafindan kalıcı ögrenmeler gerçekleştirilir." (K13E nolu öğretmen adayı ders planı)

K19K nolu öğretmen adayının ders planında da bu durum açıklanırken verilen ifadeler şunlardır:

“EK-6’da görselleri yer alan yer alan 3D modelleri strasıyla ögrrencilere göstererek bunlar hakkında öğrencilere bilgiler verilir daha sonrasında ise ögrencilerin ellerinde bulunan bu modelleri daha önce ziyaret edip etmedikleri sorulur ve modeller üzerine bir konuşma yapılır. EK-7'deki teknik sinıfa uygulanır ve hızlıca ellerinde yer alan bu modelle ilgili ilk akla gelenin ne olduğu sorulur ve cevaplar alınır. EK-8'de yer alan link ile ögrencilere $3 D$ modellerin sanal müze turuları yapılır ve ögrencilere ellerinde bulunan $3 D$ modellerin içinin nasıl olduğu gösterilir. Sanal tur bittikten sonra ellerindeki modellerle ilgili şuan da ne düşündükleri sorulur ve ilk yanıtları ile son yanıtları karşılaştırılır." (K19K nolu öğretmen adayı ders planı)

Öğretmen adaylarının 3 boyutlu yazıcılar aracılığıyla elde ettikleri modelleri farklı yöntem ve tekniklerle bütünleştirerek, öğrenci için somut, anlamlı ve kalıcı öğrenmelerin gerçekleştirilmesinde kullanmaya çalıştıkları söylenebilir. Bunun yanı sıra öğretmen adayları bu modelleri derse giriş aşamasında dikkat çekme ve derse geçiş bölümlerinde kullanmışlardır. Örneğin K3E nolu öğretmen adayı ders planındaki " $3 D$ yazıcıdan çıkartılmış Mimar Sinan heykeli getirtilerek sınıfa bu kim diye sorulur. Verilen cevaplardan sonra Mimar Sinan'ın Osmanlı döneminde yaptı̆̆ eserlerin hangileri olduğu sorularak sınıfin; hem dikkati derse çekilir hem de ön bilgi düzeyi ölçülür" biçimindeki açıklamasıyla yine K8K nolu öğretmen adayı "Öğretmen bir materyalle (3 boyutlu tesla bobini) sınıfa girer ve ögrencilerin ilgisini üzerine çeker” açıklamaları modellerin dersin dikkat çekme bölümünde kullandıklarını göstermektedir. K9K nolu öğretmen adayı da ders planında "Dersin başında ögrencilere 3 boyutlu DNA materyali gösterilerek derse geçilir” ifadesine yer vererek derse geçiş aşamasında modelden yararlandığını belirtmiştir.

\subsection{Sosyal Bilgiler Öğretmen Adaylarının 3 Boyutlu Model Ararken/Geliştirirken Yaşadıkları Sorunlar}

Araştırma kapsamında görüşülen SBÖA'larının 3 boyutlu model ararken/geliştirirken yaşadıkları sorunlar ilişkin görüşleri tekrarlanma sırasıyla "yabancı dil bilmeme", "modelleme bilgisi eksikliğì" ve "model yetersizliği" biçimindedir. Ayrıca az sayıda öğrenci herhangi bir sorun yaşamadığını dile getirmiştir.

\subsubsection{Yabancı Dil Bilmeme}

Görüldüğü gibi öğretmen adaylarının bu konuda yaşadıkları en önemli sorunlardan biri yabancı dil (İngilizce) olmuştur. Öğretmen adayları model ararken yararlandıkları sitelerin ve model isimlerinin İngilizce olması ve bu dil konusundaki yetersizlikleri nedeniyle sorun yaşadıklarını ifade etmişlerdir. Örneğin K15E nolu öğrenci bu konudaki 
görüşlerini “Siteyi hatırlamıyorum. Bulma konusunda sitenin yabancı dil olması bayağ sıkıntılıydı mesela kıtalar derken İnilizce çevirisini bulup da yapmamı gerekiyordu o biraz sıkıntılıydı. Yani bizim ülkemizde yeni kullanıldı̆̆ için herhalde o siteye falan ürünler(modeller) pek atılmamış bizde o yüzden zorlandık." biçiminde açıklarken yine K2K nolu öğretmen adayı "Bu konuda bile olsa yabancı dil eksikliğimizi gördük. Çünkü bu tarz gelişmeler hep yurt dışında oluyor yurt dışındayken sonuçta kendi dillerine göre oluşturuyorlar bu durumu bilmeyince de biz biraz uzak kalıyoruz." ifadesiyle bu durumu dile getirmiştir.

\subsubsection{Modelleme bilgisi eksikliği}

Öğretmen adaylarının yaşadıkları bir diğer sorun ise modelleme bilgisi eksikliğidir. Bu durum öğretmen adaylarının kendi modellerini oluşturamamasına ve internette bulunan hazır modellerin alınarak ders planında kullanılmasına neden olmuştur. Ders planı hazırlama sürecinde iki öğretmen adayı modelleme denemesinde bulunsa da modelleme yapamamışlardır. Öğretmen adayları bu durumu şöyle açıklamaktadırlar:

"Yani göremiyorum. Şöyle, sadece olanla yetinebiliyorum. Kendim yapabilseydim program üzerinde daha iyi olurdu diye düşünüyorum. ”(K13K)

"Geliştirme açısından biraz tabi üstüne durmam gerekiyor çünkü ben hazır olanlardan yararlandım kendim geliştirmedim onunla ilgili araştırma yapmam gerektiğini düşünüyorum." (K18K)

\subsubsection{Model yetersizliği}

Öğretmen adayları model bulma konusunda da sorunlar yaşadıklarını istedikleri her modeli internette bulamadıklarını, modellerin sınırlı olduğunu ifade etmişlerdir. Örneğin bu konuda K12E nolu öğretmen adayı "Bütün modellere hemen hemen ulaşabiliyoruz, ama yine o da sinırl ve belli bir yere kadar çok çok önemli şeyleri bulabiliyoruz." biçiminde, K1E nolu öğretmen adayı "Model tek bir renk verilmişti. Ne bileyim renklendirme yöntemiyle verilseydi daha çok etkili, daha çok kalıcı olurdu. Ancak bunu bulamadım sınırlıydı." şeklinde görüşlerini dile getirmişlerdir.

Model bulma konusunda sorun yaşamadığını belirten öğretmen adayları ise, model bulma sitelerindeki arama sekmelerine modelin adının yazıldığında doğrudan ulaşılabildiğini ve bu nedenle sorun yaşamadıklarını ifade etmişlerdir. Örneğin K10K nolu öğretmen adayı bu durumu "Derste anlattı̆̆ı̆ı bir siteden hemen İngilizcesini yazdı̆̆ımızda çıktı zaten" biçiminde, K5K nolu öğretmen adayı da "Aslında çok fazla bir şey ilk başta bakarken aklımıza gelmemişti daha sonradan baktıkça bir şeyler, fikirler üretmeye başladık. Fazla zorlanmadık." şeklinde bu durumu açıklamışlardır.

\subsection{Sosyal Bilgiler Öğretmen Adaylarının 3 Boyutlu Yazıcıların Etkili Kullanımına Yönelik Önerileri}

Araştırma kapsamında görüşülen SBÖA'larının 3 boyutlu yazıcıların etkili kullanımına yönelik önerilerine ilişkin görüşleri tekrarlanma sırasıyla "farkındalık sağlama", "ders ve seminerler", "modelleme eğitimi" "model olma ve derslerde kullanma", "kaynakları çeşitlendirme" ve "ortam sağlama" biçimindedir. 
Soyuttan somuta, sanaldan gerçeğe: öğretmen adaylarının bakış açısıyla üç boyutlu ...

\subsubsection{Farkındalık sağlama}

Öğretmen adaylarının 3 boyutlu yazıcıların etkin kullanımına yönelik olarak en fazla dile getirdikleri öneri "farkındalık sağlama" olmuştur. Öğretmen adayları bunun nedeni açıklarken, 3 boyutlu yazıcıları ve bu yazıcılar aracılığıyla alınan modelleri daha önce görmediklerini ve ilgili ders kapsamında yapılan çalışmanın kendilerinde farkındalık yarattığını, bu nedenle daha etkili kullanım için öncelikle farkındalık sağlayacak çalışmaların gerçekleştirilmesi gerektiğini belirtmişlerdir. K14E nolu öğretmen adayı bu konudaki görüşünü "Bizim en büyük sıkıntımız böyle bir teknolojinin varlı̆̆ından habersiz olmamız. Bu ders kapsamında haberdar olmamı çok güzel. Eğer üniversite ortamında böyle bir modelin, teknolojinin varlı̆̆ öğretilirse bunu kullanabiliriz." biçiminde açıklamıştır. Yine K6K nolu öğretmen adayı da "Akademisyenler bunlart öğrencilere gösterme firsatını să̆lasalar öğrenciler bunları görüp kullanabilirler. Bu derste bu modeli göstermeseydiniz, biz bilmeden buradan mezun olacaktık ve belki de hiçbir zaman programlarımızda kullanmayacaktık. Farkında olmadı̆̆ımız için." biçimindeki görüşüyle farkındalığın önemini dile getirmişlerdir.

\subsubsection{Ders ve seminerler}

Öğretmen adaylarının bir diğer önerisi ise 3 boyutlu yazıcılar ve modellemeye ilişkin derslerin açılmasıdır. Öğretmen adayları farkındalık yaratılmasının yanı sıra öğretmen adaylarının kullanım ve modelleme becerilerinin geliştirilmesine yönelik ders açılması ve seminerlerin verilmesi gerektiğini dile getirmişlerdir. K2K nolu öğretmen adayı bu konudaki görüşünü "Bence bu konuyla alakalı ayrı bir ders olması gerekiyor. Çünkü biz bu 3D yazıcısının sadece dersin bir ünite kapsamında gördük diyelim. Sadece 3D yazıcı ve $3 D$ modelleriyle alakal bir ders de olabilir" biçiminde açıklarken, K20E nolu öğrencide "Aslında teknoloji çă̆ındayız diyoruz ya, bu derslerin de ayrı bir ders, en azından yarım dönemlik bir ders şeklinde verilmesi daha uygun olur bence" biçimindeki görüşüyle ders açılması gerekliliğine vurgu yapmışlardır.

\subsubsection{Modelleme eğitimi}

Öğretmen adaylarının önerilerinden bir diğeri modelleme eğitimi verilmesidir. Çünkü öğretmen adayları modelleme yazılımları konusunda yetersiz olduklarından, model oluşturma yerine hazır modellere yöneldiklerini belirtmişlerdir. Bu durumda istedikleri her modele ulaşamamalarına neden olmuştur. Örneğin K1E nolu öğretmen adayı “Bunu biraz da kendimiz tasarlamamız lazım. Ne bileyim bir çizim yapmamız lazım, çizim yaptıktan sonra bunu teknoloji imkânı ile bilgisayarlarımıza falan geçirmemiz lazım. 3 boyutlu yazıcıya kendimiz özgün bir şey tasarlarsak daha etkili olur daha verimli olur." biçiminde görüşünü ifade etmiştir. K10K nolu öğretmen adayı ise modelleme yetersizliğinin kendilerini olumsuz etkilediğini bu nedenle kesinlikle bu tür bir eğitimin verilmesi gerekliliğini şu sözlerle açıklamıştır:

"Gelişme bölümünde biz raylı sistem olarak tasarlamıştı onu. O raylı sistemde çocuklar hareket ettirecekti Bandırma vapurunu rayl sistem üzerinde, harita üzerinde sorular sorarak mesela 'Sivas Kongresi hangi hangi tarihte yapılmıştır, toplanmıştır. Çocuklar onu harita üzerinde rayl sistem üzerinde bandırma vapurunu ilk önce Samsun'a getirip sonra Atatürk heykelini de Samsundan Sivas'a doğru hareket ettireceklerdi. Ama biz modelleme yapamadık, bu nedenle bu eğitimler verilmeli" $(\mathrm{K} 10 \mathrm{~K})$ 


\subsubsection{Model olma ve derslerde kullanma}

Öğretmen adayları özellikle Eğitim Fakültelerindeki öğretim üyelerinin, hem yenilikçi teknolojiler hem de bu teknolojilerden biri olan 3 boyutlu yazıcılar ve sosyal bilgiler eğitiminde kullanımı konusunda rol model olmaları gerektiğini vurgulamaktadırlar. $\mathrm{Bu}$ nedenle öğretim üyelerinin derslerinde bu teknolojilerden yararlanmaları ve öğretmen adaylarına uygun kullanımı göstermeleri gerektiği dile getirilmektedir. Örneğin K12E nolu öğretmen adayı bu konudaki görüşünü "Ben şöyle düşünüyorum yani bu 3 boyutlu sosyal bilgiler öğrencilerine, üniversitede okuyan öğrencilere iyi bir şekilde anlatılırsa ögretilebilir. Burada kendileri de aslında bir şeyler tasarlayabilirler ve ya var olan bir modeli alabilirler. Bunun için okullardaki derslerde kullanılması gerekir" biçiminde açıklarken, yine $\mathrm{K} 18 \mathrm{~K}$ nolu öğretmen adayı "Öğretmen adayları için tarih dersinde coğrafya dersinde ve diğer derslerde yapllabilir örnek olunabilir yani model olunması gerektiğini düşünüyorum. Ayrıca bununla ilgili yol gösterilmesi gerektiği düşünüyorum. '” biçiminde bu durumu açıklamışlardır.

\subsubsection{Kaynakları çeşitlendirme}

Öğretmen adayları özellikle yaşadıkları sorunlardan yola çıkarak 3 boyutlu modellere ilişkin kaynak çeşitliliğinin artırılması noktasında önerilerde bulunmuşlardır. Öğretmen adayları istedikleri her modele ulaşamamaları nedeniyle ve özellikle modellerin birçoğunun yabancı sitelerde yer alması nedeniyle Türkiye'ye yönelik kaynakların çeşitlendirilmesi önerisini getirmişlerdir. Örneğin bu konuda K18K nolu öğretmen aday1 "Ben şuanda araştırma yapmak istiyorum ama nerden araştırma yapmam gerektiğini bilmiyorum onunla ilgili bana kaynak sunulması gerektiğini düşünüyorum.” şeklinde görüşünü dile getirmektedir. K15E nolu öğrencide "Bu sitenin Türkçe versiyonunun olması bence daha yararlı olur ve farklı farklı modellerinde oluşturulması bence katkı sağlayacaktır." biçimindeki görüşüyle Türkçe sitelerin arttırılmasına yönelik öneri getirmiştir.

\subsubsection{Ortam sağlama}

Öğretmen adayları ayrıca fakültelerde ve ya okullarda 3 boyutlu yazıcıların kullanımına yönelik ortam sağlanması gerektiğine aksi takdirde kullanımın yetersiz kalacağına vurgu yapmaktadırlar. Örneğin K3E nolu öğretmen adayı "Bir de her okula veya fakülteye birer tane gönderilirse 3 boyutlu yazıcılardan orda öğretmenler de kendi tecrübelerinden bir şey yaparak faydalanabilir ögrenebilir. Yoksa başka türlü duyarak öğrenemeyiz, tecrübe sahibi olmalıyız." biçiminde K4E nolu öğrencide "Üniversite de belirli sinıflarda kalmaktansa $3 d$ yazıcıların aslında her fakültede her eğitim ortamında ögrencilere gösterilebileceğidir. Yani üniversite buna gerekli ortamı sağlarsa bütün ögrencilere gösterilebilir birebir şekilde.” şeklinde bu durumu açıklamışlardır.

\section{TARTIŞMA, SONUÇ ve ÖNERILER}

Sosyal bilgiler öğretmen adaylarının 3 boyutlu yazıcılar ve bu yazıcılar aracılığıyla alınan modellere ilişkin görüşlerini belirlemeyi amaçlayan bu araştırmada, öğretmen adayları 3 boyutlu yazıcılar için, "somutluk", "materyal üretimi”, "devrimsel bir teknoloji", "kolaylık", "3. boyut” ve "dokunma” temalarını kullanmışlardır. Bu kapsamda öğretmen adaylarının 3 boyutlu yazıcılar için en fazla somutluk ifadesini kullandıkları saptanmıştır. Öğretmen adayları 3 boyutlu yazıcılar ve bu yazıcılar aracılığıyla alınan modellerin soyut olan bilgileri, kavramları, görselleri, ulaşılamayacak nesneleri görselleştirerek 
Soyuttan somuta, sanaldan gerçeğe: öğretmen adaylarının bakış açısıyla üç boyutlu ...

somutlaştırdığını ve bu nedenle de ilk olarak akıllarına somutlaştırmanın geldiğini belirtmişlerdir. Bunun yanı sıra öğretmen adayları 3 boyutlu yazıcıları, öğrenme-öğretme sürecini destekleyecek materyallerin kullanışlı bir biçimde üretilebileceği, 3. boyutu öğrenme-öğretme sürecine ekleyen, dokunma duyusunu harekete geçiren ve bu bağlamda kolaylık sağlayan devrimsel bir teknoloji olarak tanımlanmıştır. Öğretmen adaylarının bu tanımları alan yazındaki 3 boyutlu yazıcıların devrimsel yönünü vurgulayan (Campbell, Williams, Ivanova ve Garrett, 2011; Ratto ve Ree, 2012; Berman, 2012; Prince, 2014) değerlendirmelerle örtüşmektedir. Bunun yanı sira 3 boyutlu yazıcılar sosyal bilgiler dersi anlamında ihtiyaç duyulan ve ulaşılamayan materyallerin üretimi kapsamında, materyal eksikliğinin giderilmesinde işe koşulabilecektir. Lütof'un (2013) belirttiği gibi düşük maliyetli üç boyutlu yazıcılar ile birlikte okul ortamlarında eğitim olanaklarını güçlendiren ve hızlı bir şekilde yazdırılabilen eğitim materyalleri üretilebilmektedir. Bu araştırmadaki öğretmen adayları da 3 boyutlu yazıcıların materyal üretimi işlevini dile getirmiş, gün geçtikçe bu teknolojinin gelişimini tamamlayarak, okul ve sınıflarda yerini alabileceğini ifade etmişlerdir.

Öğretmen adayları 3 boyutlu yazıcılar ve bu yazıcılar aracıllğıyla alınan modellerin sosyal bilgiler dersinde "somutlaştırma", "kalıcı öğrenme", "dokunarak öğrenme", "dikkat çekme ve güdülenme" ile "müze ve ders dışı gezileri sınıfa getirme" gibi katkıları olduğunu belirtmektedirler. Öğretmen adaylarının yarısından fazlasının 3 boyutlu yazıcılar ve bu yazıcılardan elde edilen modellerin sosyal bilgiler dersinde "somutlaştırma"yı sağlayacağını ifade etmişlerdir. Micallef (2015), öğrenme sürecinin bir parçası olarak, 3 boyutlu yazdırmanın, soyut kavramların sınıf içinde fiziksel nesnelere dönüştürebileceğini, bu durumunda eğitim ortamları üzerinde olumlu ve derin bir etkiye sahip olacağını belirtmektedir. Horvath'da (2014), 3 boyutlu yazdırmanın, geçmişten çok daha güçlü bir biçimde başka bir yolla mümkün olamayacak bir biçimde nesnelerin görselleştirilmesini sağladığını ve bu konuda birçok çalışma alanına katkı getirdiğini vurgulamaktadır. Sosyal bilgiler ilk ve orta öğretimde yer alan, özellikle birçok soyut kavramın somutlaştııılarak öğrencilere kazandırılması gereken bir derstir. Öğretmen adaylarının görüşlerinde belirtildiği gibi 3 boyutlu yazıcılar, özellikle sosyal bilgilerde tarih, coğrafya, ekonomi başta olmak üzere soyut bilgi, kavram, görsel ve ulaşılamayacak nesneleri somut bir biçimde öğrencinin hizmetine sunma potansiyeline sahiptir.

Öğretmen adayları üç boyutlu yazıcılar aracılığıyla elde edilen modellerin birden fazla duyu organının ișe koşulmasını sağladığını, özellikle eksikliği hissedilen dokunma duyusunun bu modeller aracılığıyla öğrenme-öğretme sürecine dâhil edilebildiğini ifade etmişlerdir. Bunun yanı sıra, sanal gezilerinde 3 boyutlu yazıcılar aracıyla somutlaşacağını belirtmişlerdir. Horowitz ve Schult (2014), fiziksel modellerin görsel ama aynı zamanda dokunma açısından inceleme imkânı sağlama avantajı olduğunu belirtir. 3 boyutlu yazıcılar dijital nesneleri, görselleri fiziksel nesnelere dönüştürerek dokunma duyusuna da hitap etmektedir. Bu durum ulaşılması zor veya imkânsız olan eser ve nesnelerin sinıflara getirilmesiyle ilk ve orta öğretim öğrencilerinin işitme ve görme duyularının yanına dokunma duyusunu da eklemelerine ve böylelikle daha kalıcı öğrenmeler sağlamalarına katkı sağlayacağı gibi görme engelli öğrenciler içinde önemli bir materyal kaynağı yaratabilecektir. Son zamanlarda görme engelliler ile yapılan pek çok çalışma bu durumu desteklemektedir (Kostakis, Niaros ve Giotitsas, 2015; Stangl, Kim ve Yeh, 2014; Scalfani ve Vaid, 2014; Gual, Pyuelo ve Lloveras, 2011 ). 
Öğretmen adayları, 3 boyutlu yazıcılar ve bu yazıcılar aracılığıyla alınacak modellerin sosyal bilgiler dersinde öğrencinin güdülenmesini ve dikkatinin çekilmesini sağlayacağını ifade etmektedirler. Öğretmen adayları bunun nedenlerini ise derse çeşitlilik katmasına, dersi monotonluktan kurtarmasına ve meraklarını çekmesine bağlamışlardır. Cano'da (2015), 3 boyutlu yazıcıların bir okulu veya sınıfı eğlenceli ve ilginç hale dönüş̧ürmenin yanı sıra öğrencinin merakını, yaratıcılığını ve öğrenme tutkusunu besleyeceğini belirtmektedir.

Öğretmen adayları 3 boyutlu yazıcıların, müze ve ders dışı geziler kapsamında gidilemeyen yerlerdeki eser ve nesnelerin sınıfa getirilmesi anlamında katkıları olacağını belirtmişlerdir. Seeger, Wall ve Herr (2016) tarafindan gerçekleştirilen çalışmada, öğretmen adayları için sınıfa getirilen müze sandıklarının, öğretmen adaylarının, tarihin belirli bir dönemi hakkındaki bilgilere ilişkin ayrıntıları hatırlamalarına, zaman dilimlerini görselleştirmelerine, reprodüksiyonların ve eserlerin amacı, kullanımı ve geçmişiyle ilgili arkadaşlarıyla tartışma ortamı oluşturmaya yardımcı olduğu saptanmıştır. Aynı zamanda pek çok öğretmen adayı, eserlere dokundurabilmenin, görmenin ve hissetmenin gerçekliği sağladığını ve zihinlerinde daha somut yaşantılar oluşturduğunu ifade etmişlerdir. İlgili çalışma kapsamında, kırsal bölgelere sağlanan bu müze sandıklarının sosyal bilgiler eğitimi açısından önemli bir firsat olduğunu dile getirilmiş̧ir. Araştırmanın bulguları, Seeger, Wall ve Herr'in (2016) müze sandıklarını araştırmasına benzer bir biçimde, 3 boyutlu yazıcıların müzeleri sınıflara ve okula getirebileceğini göstermektedir. Son yıllarda müze eğitimine yön veren önemli gelişmelerden biri bilgi iletişim teknolojisi ve araçlarındaki gelişimin müzelere yansımasıdır (Tezcan Akmehmet, 2013, s.133). Bu gelişmelere paralel olarak teknolojinin müzelere ve müze eğitimine etkileri sanal müzelerin oluşturulması ile giderek artmıştır. Pek çok müze sanal olarak gezilebilir formata dönüştürülmüştür. Ancak dünyadaki farklı müzelerin koleksiyonlarında bulunan eserlerinin 3 boyutlu yazdırılabilir modellerini erişilebilir hale getirmeleri önemli bir mihenk taşı olmuştur. Araştırmada öğretmen adaylarının da ifade ettiği gibi 3 boyutlu yazdırma teknolojisindeki gelişmeler ve dünyadaki farklı müzelerin koleksiyonlarının 3 boyutlu yazdırılabilir modellerini erişime açması müze eğitimi açsından yeni bir firsat olarak değerlendirilmelidir. $\mathrm{Bu}$ doğrultuda öğretmen adaylarına ve öğretmenlere verilecek eğitimler ve sağlanacak yazılım ve donanımlarla, dünyadaki pek çok müze, sınıf ve okullara 3 boyutlu çıktılar aracılı̆̆ıla getirilebilecektir. 3 boyutlu yazdırma teknolojisiyle birlikte, okullar ve öğretmenler dilediklerinde tematik sergiler açarak ya da ilgili koleksiyonlardan eserleri yazdırarak öğrencilerinin hem müzelere ilişkin hem de ele alınan konuya ilişkin farkındalık, bilgi, beceri ve tutumlarını geliştirmelerine yardımcı olma firsatı yakalayabileceklerdir. Bu noktada dikkat çeken bir diğer sorun, dünyadaki pek çok müzenin eserlerini 3 boyutlu yazdırılabilir formatta paylaşmasına rağmen, Türkiye'de herhangi bir müzenin bu hizmeti sağlamamasıdır. Türkiye'deki müzelerin de eserlerini tarayarak, 3 boyutlu yazdırılabilir formatta sanal ortama paylaşmaları sosyal bilgiler dersi açısından eşsiz bir kaynak oluşturacaktır.

Öğretmen adaylarının 3 boyutlu yazıcılar ve bu yazıcılar aracılı̆̆ıla alınan modellerin sosyal bilgiler dersinde kullanım alanlarına bakıldığında "tarih" ve "coğrafya" konuları ön plana çıkmıştır. Sosyal bilimlerin diğer disiplinlerindeki kullanıma ilişkin herhangi bir görüş ifade edilmemiştir. Öğretmen adayları 3 boyutlu yazıcılar ve bu yazıcılardan elde edilecek modellerden, tarihsel konuların öğretiminde özellikle kültürel mirasın öğretiminde "tarihi yapılar", "tarihi eser ve araçlar"ın kullanımında yararlanılabileceğini 
Soyuttan somuta, sanaldan gerçeğe: öğretmen adaylarının bakış açısıyla üç boyutlu ...

ifade etmektedirler. Leakey ve Dzambazova (2013), ve Pietrosemoli'de (2013), okullarda üç boyutlu yazıcılar sayesinde, öğrencilerin tarih öncesi varlıkların örneklerini canlandırması, dünyadaki önemli kültürel ve tarihi mekânların üretilmesi gibi öğrenci ve öğretmen yaratıcılığına bağlı olarak gerçekleştirilebilecek pek çok etkinlik ve proje olanağı bulunduğunu ifade etmişlerdir. Öğretmen adayları, coğrafya konularının öğretiminde ise, 3 boyutlu yazıcılardan özelikle yeryüzü şekillerinin öğretiminde ve haritaların üretiminde yararlanılabileceğini belirtmişlerdir. Horowitz ve Schult'da (2014) 3 boyutlu yazıcıların, hem dünya yüzeyi hem de dünya dışı yüzeylerin dokunmatik modellerini oluşturma yeteneğinin, eğitimcilerin öğretim materyalli repertuarını genişletmesine olanak tanıdığını belirtmektedir.

Öğretmen adaylarının ders planlarında kullandıkları modellere bakıldığında genellikle tarih ve coğrafya disiplinleri ile ilişkili olduğu yalnızca bir veya iki modelin bilim teknoloji ve ekonomi disiplinleriyle bağlantılı olduğu görülmektedir. $\mathrm{Bu}$ modellerin seçilme nedenleri incelendiğinde ise öncelikle kazanımla ilişkili olmaları, kolay ulaşılabilmeleri ve öğrenmeyi kolaylaştırıcı rol üstleneceğini düşünmeleri rol oynamıştır. Öğretmen adaylarının ders planlarında kullandıkları kazanımlar incelendiğinde öncelikle tarih ve coğrafya ile ilgili kazanımların ağırlıklı bir biçimde kullanıldı̆̆ı görülmektedir. Bunun yanı sıra ekonomi ile bilim ve teknoloji bağlantılı kazanımlarda ders planlarında kullanılmıştır. En fazla kullanılan kazanımlar ise "çevresindeki ve ülkemizin çeşitli yerlerindeki doğal varlıklar ile tarihî mekânları, nesneleri ve yapıtları tanır." ile "çeşitli ülkelerde bulunan ortak miras öğelerine örnekler verir" olmuştur. Bu kazanımların sıklıkla kullanılmasının nedeni ise internet ortamında dünya kültür mirasına ilişkin pek çok modelin yer almasıdır.

Araştırma kapsamında görüşülen SBÖA'larının 3 boyutlu model ararken/geliştirirken yaşadıkları sorunlar ise "yabancı dil bilmeme", "modelleme bilgisi eksikliği", ve "model yetersizliğiı"dir. Ayrıca az sayıda öğrenci herhangi bir sorun yaşamadığını dile getirmiştir. Öğretmen adayları model ararken yararlandıkları sitelerin ve model isimlerinin İngilizce olması ve bu dil konusundaki yetersizlikleri nedeniyle sorun yaşadıklarını ifade etmişlerdir. Öğretmen adaylarının yaşadıkları bir diğer sorun ise modelleme bilgisi eksikliğidir. $\mathrm{Bu}$ durum öğretmen adaylarının kendi modellerini oluşturamamasına ve internette bulunan hazır modellerin alınarak ders planında kullanılmasına neden olmuştur. Maloy, Kommers, Malinowski ve LaRoche (2017) tarafından gerçekleştirilen araştırmada da öğretmenler ve öğrenciler 3 boyutlu modelleme programlarının zorluğuna dikkat çekmişlerdir. Bu araştırmada da öğretmen adayları modelleme bilgisindeki eksiklikleri nedeniyle modelleme yapmakta zorlanmışlardır. Öğretmen adayları model bulma konusunda da sorunlar yaşadıklarını istedikleri her modeli internette bulamadıklarını, modellerin sınırlı olduğunu ifade etmişlerdir.

Öğretmen adaylarının 3 boyutlu yazıcıların etkili kullanımına yönelik önerileri "farkındalık sağlama", "ders ve seminerler", "modelleme eğitimi" "model olma ve derslerde kullanma", "kaynakları çeşitlendirme" ve "ortam sağlama"dır. Öğretmen adaylarının 3 boyutlu yazıcıların etkin kullanımına yönelik olarak en fazla dile getirdikleri öneri "farkındalık sağlama" olmuştur. Öğretmen adayları bunun nedeni açıklarken, yenilikçi bir teknoloji olan 3 boyutlu yazıcıları ve bu yazıcılar aracılığıyla alınan modelleri daha önce görmediklerini ve ilgili ders kapsamında yapılan çalışmanın 
kendilerinde farkındalık yarattığını bu nedenle daha etkili kullanım için öncelikle farkındalık sağlayacak çalışmaların gerçekleştirilmesi gerektiğini belirtmişlerdir.

Öğretmen adaylarının diğer önerisi ise 3 boyutlu yazıcılar ve modellemeye ilişkin derslerin açılmasıdır. Öğretmen adayları farkındalık yaratılmasının yanı sıra öğretmen adaylarının kullanım ve modelleme becerilerinin geliştirilmesine yönelik ders ve seminerlerin açılması gerektiğgini dile getirmişlerdir. Öğretmen adaylarının önerilerinden bir diğeri modelleme eğitimi verilmesidir. Çünkü öğretmen adayları modelleme yazılımları konusunda yetersiz olduklarından, model oluşturma yerine hazır modellere yöneldiklerini belirtmişlerdir. Bu durumda istedikleri her modele ulaşamamalarına neden olmuştur. Horvath (2014), öğretmenlerin yeni teknolojilere ilişkin öğrenme eğrisinin uzun sürdüğünü ve öğretmenlerin yeni araçları öğrenmek için yeterli zamana sahip olmadıklarını belirtmektedir. $\mathrm{Bu}$ nedenle öğretmen adaylarının hizmet öncesi eğitimlerinde yenilikçi teknolojilerle olabildiğince bilgi ve deneyim sahibi olmaları bu sorunun aşılmasına katkı sağlayabilecektir.

Öğretmen adayları özellikle eğitim fakültelerindeki akademisyenlerin hem yenilikçi teknolojiler hem de bu teknolojilerden biri olan 3 boyutlu yazıcilar ve sosyal bilgiler eğitiminde kullanımı konusunda rol model olmaları gerektiğini vurgulamışlardır. Bennett ve Scholes (2001) öğretmen adayların önünde meslek derslerine entegre edilmiş teknoloji bulunmadığı zaman teknolojiyi kendi alanlarında öğrenme ve öğretme faaliyetlerine uygulayamadıklarını ifade etmektedirler. $\mathrm{Bu}$ kapsamda 3 boyutlu yazdırma teknolojisinin, sosyal bilgiler öğretmeni yetiştirme programlarıyla bütünleştirilmesi ve öğretmen adaylarına bu konuda gerekli bilgi, beceri, değer ve tutumlar kazandırılması geleceğe dönük uygulamalara yansıması açısından katkı sağlayabilecektir.

Öğretmen adayları yaşadıkları sorunlardan yola çıkarak 3 boyutlu modellere ilişkin kaynak çeşitliliğinin artırılması noktasında önerilerde bulunmuşlardır. Öğretmen adayları istedikleri her modele ulaşamamaları ve modellerin birçoğunun yabancı sitelerde yer alması nedeniyle Türkiye'ye yönelik kaynakların çeşitlendirilmesi önerisini getirmişlerdir. Öğretmen adayları ayrıca fakültelerde ve ya okullarda 3 boyutlu yazıcıların kullanımına yönelik ortam sağlanması gerektiğini aksi takdirde kullanımın yetersiz kalacağına vurgu yapmaktadırlar.

Araştırmanın sonuçları çerçevesinde şu öneriler getirilebilir:

- Sosyal bilgiler öğretmen adaylarının 3 boyutlu yazıcılar ve sosyal bilgiler eğitiminde kullanımı konusunda farkındalıklarını artıracak çalışmalar gerçekleştirilmelidir. Bu kapsamda teknoloji ile bağlantılı bir ders içerisinde veya seminerler yoluyla bu farkındalık sağlanmaya çalışılmalıdır.

- Eğitim Fakültelerinde öğretmen adaylarının yararlanabileceği bir 3 boyutlu yazdırma odası açılarak, öğretmen adaylarına bu teknolojiden yararlanabilecekleri bir ortam sağlanmalıdır.

- Sosyal bilgiler öğretmen adaylarının yabancı bir dilde ara yüzü bulunan teknolojik ürünleri, yazılımları ve internet sitelerini kullanabilecekleri düzeyde dil yeterliliklerinin ve aynı zamanda dijital okuryazarlık becerilerinin geliştirilmesine yönelik çalışmalar gerçekleştirilmelidir. 
Soyuttan somuta, sanaldan gerçeğe: öğretmen adaylarının bakış açısıyla üç boyutlu ...

- Sosyal bilgiler öğretmen adaylarının 3 boyutlu yazıcıları etkili bir biçimde kullanmalarına yönelik örnekler içeren kitap, makale gibi yayınlar gerçekleştirilmelidir.

- İleriye dönük araştırmalar kapsamında, öğretmen adaylarının kendi 3 boyutlu modellerini tasarlamalarına ve yazdırmalarına yönelik eylem araştırmaları; 3 boyutlu yazıcıların sosyal bilgiler eğitiminde kullanımının etkililiğine yönelik deneysel araştırmalar; Sosyal bilgiler öğretmenlerinin 3 boyutlu yazıcılar ve sosyal bilgiler eğitiminde kullanımına yönelik farkındalıklarını belirlemeye yönelik nicel ve nitel araştırmalar gerçekleştirilebilir. 


\section{KAYNAKÇA}

Balcıoğlu, Y. S. (2014). 3 boyutlu yazıcı ve sinemada kullanımı. Yayımlanmamış Yüksek Lisans Tezi. Yaşar Üniversitesi, Sosyal Bilimler Enstitüsü, İzmir.

Bennett, L., and Scholes, R. (2001). Goals and attitudes related to technology use in a social studies method course. Contemporary Issues in Technology and Teacher Education, 1(3), 373-385.

Berman, B. (2012). 3-D printing: The new industrial revolution. Business Horizons, 55(2), 155-162. doi: 10.1016/j.bushor.2011.11.003

Berson, M. J., and Balyta, P. (2004). Technological thinking and practice in the social studies: Transcending the tumultuous adolescence of reform. Journal of Computing in Teacher Education, 20(4), 141-150. doi: $\underline{10.1080 / 10402454.2004 .10784498}$

Buehler, E., Kane, S. K. and Hurst, A. (2014). ABC and 3D: opportunities and obstacles to $3 \mathrm{D}$ printing in special education environments. Proceedings of the 16th international ACM SIGACCESS Conference on Computers \& Accessibility, 107-114. doi: $10.1145 / 2661334.2661365$

Byun, M. K., Jo, J. H., and Cho, M. H. (2015). The analysis of learner's motivation and satisfaction with 3D printing in science classroom. Journal of the Korean Association for Science Education, 35(5), 877-884. doi: $\underline{10.14697 / \mathrm{jkase} .2015 .35 .5 .0877}$

Campbell, T., Williams, C., Ivanova, O., and Garrett, B. (2011). Could 3D printing change the world. Technologies, Potential, and Implications of Additive Manufacturing, Atlantic Council, Washington, DC.

Cano, L. M. (2015). 3D printing: a powerful new curriculum tool for your school library. California: ABC-CLIO, LLC.

Creswell, J.W. (2007). Qualitative inquiry research design choosing among five approaches. Thousand Oaks, California: Sage Publications.

Costello, J. P., Olivieri, L. J., Krieger, A., Thabit, O., Marshall, M. B., Yoo, S. J., ... and Nath, D. S. (2014). Utilizing three-dimensional printing technology to assess the feasibility of high-fidelity synthetic ventricular septal defect models for simulation in medical education. World Journal for Pediatric and Congenital Heart Surgery, 5(3), 421-426. doi: 10.1177/2150135114528721

Demir Kuzu, E. B., Çaka, C., Tuğtekin, U., Demir, K., İslamoğlu, H. ve Kuzu, A. (2016). Üç boyutlu yazdırma teknolojilerinin eğitim alanında kullanımı: Türkiye'deki uygulamalar. Ege Eğitim Dergisi, 2(17), 481-503.

Golub, M., Guo, X., Jung, M., and Zhang, J. (2016). 3D printed ABS and carbon fiber reinforced polymer specimens for engineering education. In Rewas, (pp. 281285). Springer International Publishing. doi: 10.1007/978-3-319-48768-7 43

Glesne, C. (2012). Nitel araştırmaya giriş. (A. Ersoy ve P. Yalçınoğlu, Çev. Ed.). Ankara: Anı Yayıncılık (Orjinal çalışma basım tarihi 1992). 
Soyuttan somuta, sanaldan gerçeğe: öğretmen adaylarının bakış açısıyla üç boyutlu ...

Greenhalgh, S., and Greenhalgh, S. (2016). The effects of 3D printing in design thinking and design education. Journal of Engineering, Design and Technology, 14(4), 752-769. doi: 10.1108/JEDT-02-2014-0005

Gual, J., Puyuelo, M. and Lloveras, J. (2011). Universal design and visual impairment: tactile products for heritage access. In DS 68-5: Proceedings of the 18th International Conference on Engineering Design (ICED 11), Impacting Society through Engineering Design, Vol. 5: Design for X/Design to X, Lyngby/Copenhagen, Denmark, 15.-19.08. 2011.

Hamidi, F., Young, T. S., Sideris, J., Ardeshiri, R., Leung, J., Rezai, P. and Whitmer, B. (2017). Using robotics and 3D printing to introduce youth to computer science and electromechanical engineering. Proceedings of the 2017 CHI Conference Extended Abstracts on Human Factors in Computing Systems, 942-950. doi: $\underline{10.1145 / 3027063.3053346}$

Hausman, K. (2013). 3D printing for dummies. Hoboken, NJ: John Wiley \& Sons.

Horowitz, S. S., and Schultz, P. H. (2014). Printing space: Using 3D printing of digital terrain models in geosciences education and research. Journal of Geoscience Education, 62(1), 138-145. doi: 10.5408/13-031.1

Horvath, J. (2014). Mastering 3D printing. New York: Apress.

Horvath, J. and Cameron, R. (2015). 3D Printing with mattercontrol. New York: Apress.

Horvath, J., Cameron, R. and Adrianson, D. (2015). The new shop class: Getting started with $3 D$ printing, Arduino, and wearable tech. New York: Apress.

Hoy, M. B. (2013). 3D printing: making things at the library. Medical Reference Services Quarterly, 32(1), 93-99. doi: 10.1080/02763869.2013.749139

Huleihil, M. (2017, January). 3D printing technology as innovative tool for math and geometry teaching applications. In IOP Conference Series: Materials Science and Engineering (Vol. 164, No. 1, p. 012023). IOP Publishing.

Kostakis, V., Niaros, V., and Giotitsas, C. (2015). Open source 3D printing as a means of learning: An educational experiment in two high schools in Greece. Telematics and Informatics, 32(1), 118-128. doi: 10.1016/j.tele.2014.05.001

Leakey, L., and Dzambazova, T. (2013). Prehistoric collections and 3D printing for education. E., Fonda, C., \& Zennaro, M. (Ed.), in Low-Cost 3D Printing for Science, Education and Sustainable Development (s.159-163). ICTP Science Dissemination Unit.

Lee, I. H., Shin, J. M., and Cho, H. Y. (2015). Design and operation of 3D printing education curriculum in mechanical engineering. Journal of the Korean Society of Manufacturing Process Engineers, 14(3), 21-26. doi: $\underline{10.14775 / \mathrm{ksmpe} .2015 .14 .3 .021}$

Lütolf, G. (2013). Using 3D printers at school: The Experience of 3drucken.ch. Canessa, E., Fonda, C., \& Zennaro, M. (Ed.), in Low-Cost 3D Printing for Science, Education and Sustainable Development (s.149-159). ICTP Science Dissemination Unit. 
Maloy, R., Kommers, S., Malinowski, A., and LaRoche, I. (2017). 3D Modeling and printing in history/social studies classrooms: Initial lessons and insights. Contemporary Issues in Technology and Teacher Education, 17(2), 229-249.

Martin, R. L., Bowden, N. S., and Merrill, C. (2014). 3D printing in technology and engineering education. Technology and Engineering Teacher, 73(8), 30-35.

Micallef, J. (2015). Beginning design for 3D printing. New York: Apress.

Nichols, S., Schuster, T., and Ball, M. (2016). Using a public library makerspace to bring STEM education to low-income youth. Gulf South Summit on ServiceLearning. 38.

Park, K. (2014). Applications of 3D CAD and 3D printing in engineering design education. Journal of the Korean Society for Precision Engineering, 31(12), 1085-1091. doi: 10.7736/KSPE.2014.31.12.1085

Patton, M. Q. (2002). Qualitative research \& evaluation methods. Thousand Oaks, CA: Sage Publications.

Pietrosemoli, D. (2013). 3D Printing in art installations. E., Fonda, C., \& Zennaro, M. (Ed.), in Low-Cost 3D Printing for Science, Education and Sustainable Development (p.163-169). ICTP Science Dissemination Unit.

Prince, J. D. (2014). 3D printing: An industrial revolution. Journal of Electronic Resources in Medical Libraries, 11(1), 39-45. doi: $10.1080 / 15424065.2014 .877247$

Ratto, M., and Ree, R. (2012). Materializing information: 3D printing and social change. First Monday, 17(7).

Scalfani, V. F. and Vaid, T. P. (2014). 3D printed molecules and extended solid models for teaching symmetry and point groups. Journal of Chemical Education, 91(8), 1174-1180. doi: $\underline{10.1021 / \mathrm{ed} 400887 \mathrm{t}}$

Schaffhauser, D. (2013). 3D printing, gamification to impact STEM education within three years. THE Journal (Technological Horizons In Education), 40(11), 5.

Seeger, V., Wall, T. J. and Herr, L. J. (2016). Museum trunks: Making an impact on future teachers of social studies. Journal of Museum Education, 41(2), 131140. doi: $10.1080 / 10598650.2016 .1169736$

Stangl, A., Kim, J. and Yeh, T. (2014). 3D printed tactile picture books for children with visual impairments: A design probe. Proceedings of the 2014 Conference on Interaction Design and Children, 321-324. doi: 10.1145/2593968.2610482

Straub, J., Berk, J., Nordlie, J., and Marsh, R. (2015, April). The use of low-cost 'BalloonSats' for STEM education with 3D printing. In Third Annual North Dakota Space Robotics Forum.

Taylor, B. (2016). Evaluating the benefit of the maker movement in K-12 STEM education. Electronic International Journal of Education, Arts, and Science, 2 . 
Soyuttan somuta, sanaldan gerçeğe: öğretmen adaylarının bakış açısıyla üç boyutlu ...

Tezcan Akmehmet, K. (2013). Müzeler ve eğitim. Altınsapan, E ve Küçükhasköylü, N (Ed.), Müzecilik ve Sergileme (s.128-155). Eskişehir: Açıköğretim Fakültesi Yayınlar1.

Türnüklü, A. (2000). Eğitim bilim araştırmalarında etkin olarak kullanılabilecek nitel bir araştırma tekniği: Görüşme. Kuram ve Uygulamada Eğitim Yönetimi Dergisi, 6(4), 543-559.

Vaccarezza, M., and Papa, V. (2015). 3D printing: a valuable resource in human anatomy education. Anatomical Science International, 90(1), 64-65. doi: $10.1007 / \mathrm{s} 12565-014-0257-7$

Vanscoder, J. (2014,). 3D printing as a tool for teaching and learning in STEAM education. In Society for Information Technology \& Teacher Education International Conference (pp. 188-191). Association for the Advancement of Computing in Education (AACE).

Williams, Linda D. (2015). Additive manufacturing or 3d scanning and printing. in Manufacturing Engineering Handbook. New York: McGraw-Hill.

Yıldırım, A., and Şimşek, H. (2005). Sosyal bilimlerde nitel araştırma yöntemleri. Ankara: Seçkin Yayıncılık. 


\section{EXTENDED ABSTRACT}

\section{Introduction}

In recent years, as a method for creating physical objects out of digital designs (Hoy, 2013), three-dimensional printing has started to be used in many areas including medicine, engineering, arts and education. In an issue published in 2011, The Economist refers to three-dimensional printing as "the technology that will change the world" (Ratto \& Ree, 2012), and it is foreseen that this technology will bring a revolutionary change like the steam engine, atomic energy, microchips and Internet (Campbell, Williams, Ivanova \& Garrett, 2011; Goodrich, 2014).

Due to the software generated with the RepRap project that aims to produce free software for three-dimensional printers, there has been a significant decline in the prices of these devices, which opened the door for the use of consumers (Hausman, 2013). Individuals can now have their personal three-dimensional printers without having to pay very high costs, and this has brought increasing interest in this technology. Low-cost threedimensional printers have led to the development of instructional materials that strengthen educational opportunities in school environments and can be produced easily (Lütolf, 2013).

Since the use of three-dimensional printers in educational environments is quite new, there are limited studies in this area. Although most of these studies were conducted at higher education level, some studies focused on elementary and middle school levels. These studies were of different subject areas such as engineering education (Martin, Bowden \& Merrill, 2014; Golub, Guo, Jung \& Zhang, 2016; Lee, Shin \& Cho, 2015; Park, 2014).), robotics education (Hamidi et al., 2017), special education (Buehler, Kane \& Hurst, 2014), anatomy education (Vaccarezza \& Papa, 2015), medical education (Costello et al., 2014), geosciences education (Horowitz \& Schultz, 2014), design education (Greenhalgh \& Greenhalgh, 2016), science education (Byun, Jo \& Cho, 2015), STEM education (Schaffhauser, 2013; Straub, Berk, Nordlie \& Marsh, 2015; Taylor, 2016; Nichols, Schuster \& Ball 2016; Vanscoder, 2014), and mathematics and geometry education (Huleihil, 2017). However, studies that relate to social studies education (Maloy, Kommers, Malinowski \& LaRoche, 2017) are quite limited.

The aim of this study was to identify the views of social studies teacher candidates on three dimensional printers and the models obtained through these printers, and the effects of these models on the social studies course.

\section{Method}

Phenomenology was employed in this study that aimed to examine the views of social studies teacher candidates (SSTCs) on three dimensional printers and the models obtained through these printers, and the effects of these models on the social studies course.

\subsection{Participants}

Criterion sampling, a purposeful sampling method, was used in the selection of the participants. The sample consisted of 20 students (11 male and 9 female) who were studying social studies education in the 2015-2016 academic year and were members of the 20 groups (one student from each group) who prepared lesson plans related to three- 
Soyuttan somuta, sanaldan gerçeğe: öğretmen adaylarının bakış açısıyla üç boyutlu ...

dimensional printers in the "Examinations of Social Studies Course Book" course. In the scope of the study, a two-hour presentation on three-dimensional printers and their use in social studies education was delivered to 63 students who have taken the coursebook evaluation course at the beginning of the term. The class was divided into 20 groups of three and/or four and asked to prepare a lesson plan in which these printers are used.

\subsection{Data Gathering}

In the study, semi-structured interviews and document analysis were conducted to gather data. In the interviews, the teacher candidates were asked ten questions related to what three-dimensional printers mean to them, their experiences, the effect of these printers on social studies education and their use in the social studies course, the problems they encountered in the process, and their suggestions. The interviews were carried out in November and December of 2015 and lasted about 20 to 30 minutes each.

\subsection{Data Analysis}

An inductive approach was adopted in the analysis of the data gathered in the study. In order to enhance the trustworthiness of the study, $20 \%$ of the raw interview data were coded by an independent field expert. The data were presented along with direct quotations from the teacher candidates' views.

\section{Findings, Result and Discussion}

The social studies teacher candidates stated that three-dimensional printers and the models produced with these printers made abstract information, concepts, visuals and unreachable objects concrete, and that is why they firstly thought of concretisation. In addition, they defined three-dimensional printers as a revolutionary technology that can produce materials to support the instructional process in a useful way, adds the third dimension to this process, triggers the sense of touch, and in this regard, makes learning easier. These definitions of the teacher candidates are consistent with the evaluations that emphasise the revolutionary aspect of three-dimensional printers in the literature (Campbell, Williams, Ivanova \& Garrett, 2011; Ratto \& Ree, 2012; Berman, 2012; Goodrich, 2014; Prince, 2014). The teacher candidates also said that three-dimensional printers could be employed to address the lack of materials in the social studies course. These views of teacher candidates overlap with Lütof's (2013) emphasis on the role of these printers in strengthening educational opportunities and developing educational materials quickly.

The social studies teacher candidates asserted that three-dimensional printers and the models produced with them could affect the social studies course in terms of "concretisation", "permanent learning", "learning by touch", "attracting attention and motivation" and "bringing museums and extracurricular trips to the class". These findings are in line with Micallef (2015) and Horvath's views (2014) regarding the visualization of objects and turning abstract concepts to physical objects in the class. The teacher candidates also stated that the sense of touch could be used in the instructional process by means of three-dimensional printers. Horowitz and Schult (2014) indicate that physical models have the advantage of examination visually but also in terms of touch. Three-dimensional printers address the sense of touch by turning digital objects and visuals into physical objects. 
Another result of the study is that three-dimensional printers could be of use in bringing to class the works and objects that cannot be visited in museums and trips. In their study, Seeger, Wall and Herr (2016) report that museum crates are an important opportunity for social studies education. The results of the study show that three-dimensional printers could bring museums to class and school, similar to museum crates.

The teacher candidates specified that three-dimensional printers could be used in history teaching by modelling "historical structures" and "historical works and tools". In this regard, Leakey and Dzambazova (2013) and Pietrosemoli (2013) state that thanks to three-dimensional printers, students have opportunities for many activities and projects such as visualising prehistorical creatures, and modelling significant cultural and historical places in the world. As for teaching geography, the teacher candidates said that three-dimensional printers could be used to teach land forms and produce maps. Similarly, Horowitz and Schult (2014) state that three-dimensional printers' ability to model both earth surface and extraterrestrial surfaces enable educators to expand their repertoire of instructional materials.

The models that the teacher candidates used in their lesson plans were mostly related to history and geography, while only one or two models were related to science, technology and economy. The problems that the SSTCs mentioned having while looking for/developing three-dimensional models were "not speaking a foreign language", "lack of knowledge in modelling" and "limited number of models". Besides, a small number of the candidates said they did not have any problems. One of the problems they had was the lack of knowledge in modelling. In Maloy, Kommers, Malinowski and LaRoche (2017), the teachers and students underlined the difficulty of three-dimensional modelling programs.

The teacher candidates' suggestions regarding the effective use of three-dimensional printers included "raising awareness", "courses and seminars" "training for modelling", "using modelling in class", "diversifying resources" and "arranging a suitable environment". The most common suggestion of the teacher candidates regarding the effective use of three-dimensional printers was "raising awareness". In addition, the teacher candidates pointed out that the academics at education faculties should be role models in both innovative technologies and three-dimensional printers, and their use in social studies education. Bennett and Scholes (2001) state that when teacher candidates do not have technology integrated into their vocational courses, they cannot learn and teach by using technology in their areas.

Based on the results of the study, the following suggestions can be offered:

- Practices (e.g. courses, seminars, etc.) should be implemented to raise teacher candidates' awareness regarding three-dimensional printers and their use in social studies education.

- Academics in social studies education should show students how to use threedimensional printers in instruction in methodology courses, and be role models in this respect.

- In education faculties, teacher candidates should be provided with a threedimensional printing room in which they can experience and use this technology. 
Soyuttan somuta, sanaldan gerçeğe: öğretmen adaylarının bakış açısıyla üç boyutlu ...

- The number of publications such as books and articles should be increased which include samples for using three-dimensional printers effectively.

- Suggestions for further research include action research studies on teacher candidates' designing and printing their own three-dimensional models, experimental studies on the effectiveness of three-dimensional printers in social studies education, and quantitative and qualitative studies to examine social studies teachers' awareness regarding three-dimensional printers and their use in social studies education. 